\title{
FRP reinforced-concrete slabs: a comparative design study
}

DOI:

10.1680/jstbu. 16.00055

\section{Document Version}

Accepted author manuscript

Link to publication record in Manchester Research Explorer

\section{Citation for published version (APA):}

Stuart, V., \& Cunningham, L. (2017). FRP reinforced-concrete slabs: a comparative design study. Proceedings of the Institution of Civil Engineers: Structures and Buildings, 170(8), 581-602. https://doi.org/10.1680/jstbu.16.00055

\section{Published in:}

Proceedings of the Institution of Civil Engineers: Structures and Buildings

\section{Citing this paper}

Please note that where the full-text provided on Manchester Research Explorer is the Author Accepted Manuscript or Proof version this may differ from the final Published version. If citing, it is advised that you check and use the publisher's definitive version.

\section{General rights}

Copyright and moral rights for the publications made accessible in the Research Explorer are retained by the authors and/or other copyright owners and it is a condition of accessing publications that users recognise and abide by the legal requirements associated with these rights.

\section{Takedown policy}

If you believe that this document breaches copyright please refer to the University of Manchester's Takedown Procedures [http://man.ac.uk/04Y6Bo] or contact uml.scholarlycommunications@manchester.ac.uk providing relevant details, so we can investigate your claim.

\section{OPEN ACCESS}


Title: FRP Reinforced Concrete Slabs: A Comparative Design Study

\section{Author 1:}

Valerio Stuart, BSc, MSc

Structural Engineer at WSP, Manchester UK

\section{Author 2:}

Lee S. Cunningham, MEng, PhD, CEng, MICE, MIStructE, MASCE, FHEA

Lecturer at The University of Manchester, School of Mechanical, Aerospace and Civil Engineering, Manchester, UK 


\title{
Abstract
}

Durability of concrete structures represents a major challenge today for both existing and new structures. Fibre- reinforced polymer (FRP) composite rebar offers a highly durable alternative to steel rebar. Research on the use of FRP rebar has been conducted over the past 40 years; however, its widespread application is yet to occur. This paper investigates the use of FRP as reinforcement, in particular the application to slab elements and associated performance at serviceability and ultimate limit state. Existing design guidance such as the $\mathrm{ACl}$ and CSA standards are reviewed and a number of slab designs with dimensions common in practice are undertaken. $A$ third approach that follows the Eurocode design philosophy is also reviewed. The design of the different slab forms is assessed according to these codes, and results compared with the behaviour predicted by non-linear finite-element analysis. The relative costs of each resulting slab design are also discussed. The findings highlight differences in the relative accuracy of the different code recommendations and indicate the need for further research to exclude potentially non-conservative design. The work presented is intended to provide a contextual comparison of existing design approaches, which will be useful to practitioners involved in design of concrete structures with FRP rebar.

\section{Keywords chosen from ICE Publishing list}

Composite structures, Concrete structures, Design methods and aids

\author{
List of notation (examples below) \\ $A_{f}, A_{f r p}$ Area of longitudinal FRP reinforcement, $\mathrm{mm}^{2}$ \\ $A_{s} \quad$ Area of longitudinal steel reinforcement, $\mathrm{mm}^{2}$ \\ a Depth of stress block, $\mathrm{mm}$ \\ b Width of rectangular cross section, $\mathrm{mm}$ \\ C Resultant of compressive stresses in concrete, $\mathrm{N}$ \\ c Depth of neutral axis, $\mathrm{mm}$ \\ $\mathrm{C}_{\mathrm{b}}$ depth of neutral axis at the balanced failure condition, $\mathrm{mm}$ \\ d Distance from extreme compression fibre to centroid of tension reinforcement, $\mathrm{mm}$ \\ $E_{f} \quad$ Design value of modulus of elasticity of FRP, MPa
}


$E_{\mathrm{fk}} \quad$ Characteristic value of modulus of elasticity of FRP, MPa

$E_{s} \quad$ Design value of modulus of elasticity of reinforcing steel, MPa

$\mathrm{f}_{\mathrm{c}}^{\prime} \quad$ Specified compressive strength of concrete, MPa

$\mathrm{f}_{\mathrm{cd}} \quad$ Design value of concrete compressive strength, MPa

$\mathrm{f}_{\mathrm{ck}} \quad$ Characteristic value of concrete compressive strength, MPa

$\mathrm{f}_{\mathrm{ctm}} \quad$ Mean value of concrete tensile strength, MPa

$f_{f}, f_{\text {frp }} \quad$ Stress in FRP, MPa

Tensile strength of FRP bars, MPa

$\mathrm{f}_{\mathrm{fu}} \quad$ Design tensile strength of FRP, considering reductions for service environment, MPa Ultimate tensile strength of FRP bars, $\mathrm{MPa}$

$\mathrm{f}_{\mathrm{fk}} \quad$ Characteristic value of tensile strength of FRP reinforcement, $\mathrm{MPa}$

$\mathrm{f}_{\mathrm{yd}} \quad$ Design yield strength of steel reinforcement, MPa

$\mathrm{f}_{\mathrm{yk}} \quad$ Characteristic yield strength of reinforcement, MPa

$\frac{f_{\beta 0}}{f_{c 0}} \quad$ Ratio of the strength in the biaxial compression state to the strength in the uniaxial state

G permanent action

$\mathrm{G}_{\mathrm{k}} \quad$ Characteristic value of permanent action

$\mathrm{I}_{\mathrm{cr}} \quad$ Moment of inertia for cracked concrete section

$\mathrm{I}_{\mathrm{e}} \quad$ Effective moment of inertia, $\mathrm{mm}^{4}$

$\mathrm{I} \quad$ Moment of inertia of gross concrete section, $\mathrm{mm} 4$

$\mathrm{I}_{\mathrm{t}} \quad$ Moment of inertia for uncracked section transformed to concrete, $\mathrm{mm} 4$

$\mathrm{K}_{\mathrm{c}} \quad$ Distances between the hydrostatic axis and the compression and tension meridian in the deviatoric cross section respectively

L Span, $\mathrm{mm}$

$\mathrm{L}_{\mathrm{x}} \quad$ Element length in the longitudinal direction, $\mathrm{mm}$

$\mathrm{M}_{\mathrm{cr}} \quad$ Applied moment causing the occurrence of the first crack, $\mathrm{kNm}$

$\mathrm{M}_{\mathrm{n}} \quad$ Nominal moment capacity, Nmm

$\mathrm{M}_{\mathrm{u}} \quad$ Factored moment at section, $\mathrm{Nmm}$

P Uniform distributed load applied along the loading line

Q variable action

$Q_{k} \quad$ characteristic value of a single variable action

$\mathrm{T}$ Internal force due to tension in FRP reinforcement, $\mathrm{N}$ 


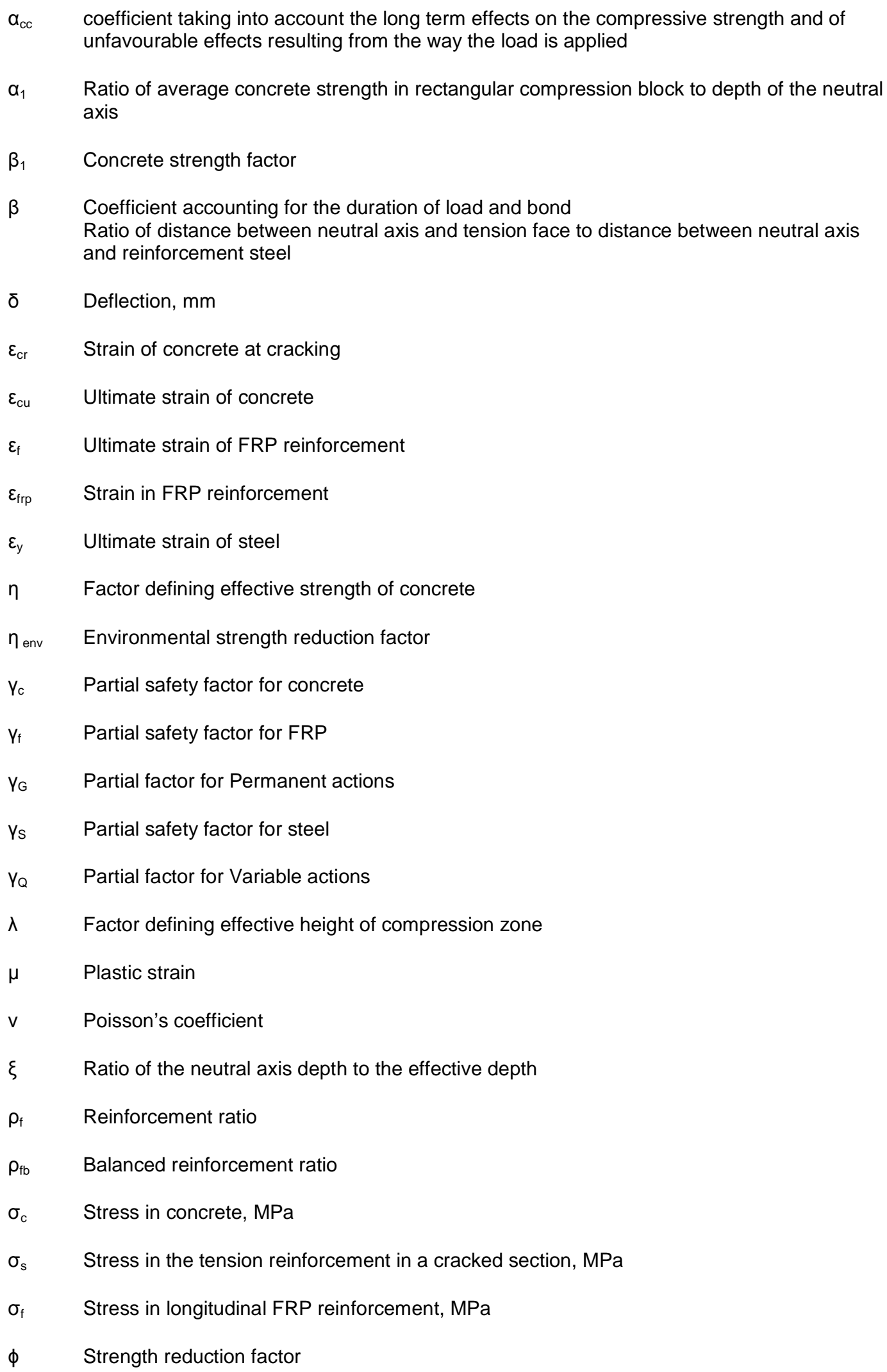





\section{Introduction}

\subsection{Background}

Different applications of fibre-reinforced polymers (FRPs) are available in the civil engineering field, with the use of FRP strips or bars to externally repair or strengthen structural elements being the most well-known and common technique. The technique investigated in this study involves the substitution of traditional steel reinforcement with FRP bars. This is particularly convenient in aggressive environments, where the FRP is able to guarantee better long-term performances than unprotected steel reinforcement (Mertol et al., 2006).

The use of FRP materials for civil engineering applications was considered for the first time in the 1960s to solve the problem of corrosion of highway bridges, and of structures heavily exposed to marine salt or subjected to de-icing salt. However, at that time FRP reinforcing bars were not commercially available and the first applications took place only in the 1980s. Initially, FRP reinforcement was used in bridge decks (Clarke et al., 1998; Weaver, 1995), in facilities for magnetic resonance imaging (MRI) medical equipment, seawall construction (Cunningham and Burgess, 2012; Cunningham et al., 2012; Nanni and Dolan, 1993), substation reactor bases, airport runways and electronics laboratories. During the first half of the 1990s, FRP applications were widespread in Japan; then later, during the early 2000s, China became the largest user of FRP materials. In 1986, the first prestressed FRP highway bridge was built in Germany, and the use of FRP reinforcement started to spread in Europe $(\mathrm{ACl}, 2006)$. Among the latest examples in the UK are the new central area coastal defences in Blackpool, completed in late 2010 and the largest single application of FRP at the time. To avoid the corrosion of reinforcement bars and related phenomena, such as spalling or staining, the design team adopted FRP-reinforced precast concrete (Cunningham and Burgess, 2012; Cunningham et al., 2012; also see Figure 1). Stainless steel is usually used for this type of application; however, owing to the market price fluctuation of the material, the design team used the fibre-reinforced composite reinforcement instead. This project proved that the material can be used in large-scale projects and that the geo- metrical constraint due to the nature of the reinforcement can be overcome with careful detailing. Nowadays, despite the potential of FRP materials for civil engineering applications and the benefits they offer as an alternative to steel rebar, the use of FRP is still not widespread. One of the reasons for this is the relative lack of design codes for FRP structures 
(Shave, 2014). In Europe, although there are Eurocodes for the common construction materials, there is not one for FRP structures. Therefore, only specialists who already possess a considerable amount of knowledge and understanding of the material usually embrace the design of such structures, and many designers lack familiarity with the material. It is clear that FRP materials are a possible and effective alternative to steel reinforcing bars for concrete structures, and as their physical and mechanical behaviour is different from that of steel (e.g. see Table 1), a specific guidance on their use is necessary. Another obstacle for the wide- scale uptake of FRP rebar is the absence, unlike for steel rebar, of uniform quality standards. Every manufacturer produces and certifies a different product, which makes the use of the material more complex (Gremel, 2012; Railway Technology, 2007).

41

42

43

44

45

46

\begin{tabular}{|l|l|l|l|l|}
\hline & GFRP & CFRP & AFRP & Steel \\
\hline $\begin{array}{l}\text { Yield stress } \\
(\mathrm{MPa})\end{array}$ & - & - & - & 276 to 517 \\
\hline $\begin{array}{l}\text { Tensile strength } \\
(\mathrm{MPa})\end{array}$ & 483 to 1600 & 600 to 3690 & 1720 to 2540 & 483 to 690 \\
\hline $\begin{array}{l}\text { Elastic modulus } \\
(\mathrm{GPa})\end{array}$ & 35.0 to 51.0 & 120.0 to 580.0 & 41.0 to 125.0 & 200 \\
\hline Yield strain & - & - & - & 0.14 to 0.25 \\
\hline Rupture strain & 1.2 to 3.1 & 1.2 to 3.1 & 1.9 to 4.4 & 6.0 to 12.0 \\
\hline
\end{tabular}

Figure 1. Tower headland wave-wall unit reinforcement cage. Straight glass FRP bars at the coffered portion used in combination with steel bars in the ribs (Cunningham and Burgess, 2012)

Table1 Common tensile properties of reinforcing bars, with typical values for fibre volume fractions ranging from 0.5 to 0.7

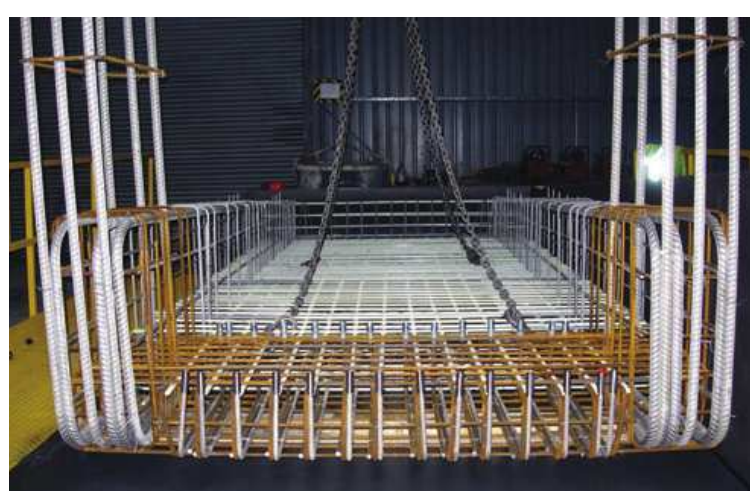


51

52

54 The aim of this study is provide a comparison between avail- able codes and assess their 55

\subsection{Aim and Scope}

prediction against finite-element (FE) models. It is essential to highlight the lack of comparative studies of FRP rebar codes; at the time of writing, there are only a few publications readily available in the literature (Cosenza et al., 1997; International Federation for Structural Concrete (fib) - TG 9.3 (fib, 2007); Pilakoutas et al., 2011).

In this study, the performance of FRP as reinforcement and its application to reinforcedconcrete $(\mathrm{RC})$ slabs will be assessed. For this purpose, several structural elements are modelled using the commercially available FE software Abaqus, to reproduce the non-linear behaviour of the structure. In addition, different codes are presented and used to design the structural elements that are finally tested using Abaqus. The key point of the paper is to assess the relative accuracy of the code predictions of ultimate strength. This is a critical problem: considering the elevated cost of the material in relation to normal steel rebar, an overly conservative design will not be economic. At the same time, however, to guarantee a safe design, the performance of the designed element and in particular the mode of failure need to be properly investigated, especially under certain environmental and/or load conditions.

This study focuses on flexure and the slabs designed in Section 3 were chosen such that flexural failure governs.

\section{Codes and Design}

\subsection{Available codes}

Several codes on the design of RC structures with FRP are available. Both the USA (ACl, 2003, 2006) and Canada (CSA, 2002; ISIS Canada, 2007) have published and revised specific guidelines and codes. The 'Eurocrete' research project was started in 1993 and delivered a set of design guidelines in 1996, focusing on the development of FRP rebars for concrete (Clarke et al., 1996). As part of the research project, the first completely FRP reinforced footbridge was installed in the UK in 1996. In the UK, the Institution of Structural Engineers (IStructE) published a technical report providing design guidance in 1999 (IStructE, 1999), following the work done by the Eurocrete project. Other countries such as Italy (CNR, 2006) have published their recommendations, while other inter- national bodies are carrying out experimental studies and 
publishing technical reports ( fib - TG 9.3 ( fib, 2007)). Unlike for other construction materials such as concrete, steel and timber, there is no Eurocode available for $\mathrm{RC}$ elements reinforced with embedded FRP rebar. For the scope of this study, a design approach based on the Eurocode philosophy was adopted, drawing on guidance on different European sources following the steps illustrated in Figure 2. Because the fib (see Table 2) document is the closest to the Eurocodes for its international nature, it will be considered as the principal source for the design of the FRP RC elements. For those cases where equations provided by non-European codes are recommended over adapted Eurocode equations, or no adapted Eurocode equations are provided, the Italian National Research Council (CNR) equations were used.

\subsection{Ultimate Limit State}

Considering a balanced typical steel RC section, with a steel strength to stiffness ratio similar to that of concrete, the neutral axis depth is usually not far above the middle of the effective depth. As for FRP reinforcement, the strength to stiff- ness ratio is greater by an order of magnitude, and the neutral axis depth is very close to the compressive end, as shown in Figure 3. Therefore for FRP RC elements, if the section is balanced, a large part of the cross-section is subjected to tensile strain at rupture. This causes large flexural deflections and cracks where the concrete is under tension. Owing to the large difference in stiffness between an uncracked and a cracked section, the stress in the bars and the deflection vary substantially between the two sections. The large amount of cross-section subjected to tensile strain can be decreased either by pre-stressing or increasing the amount of reinforcement. However, considering that an FRP RC section with of $\geq 0.5 \%$ is over-reinforced, increasing the amount of reinforcement will lead to higher costs, larger short-term deformations due to the high strains needed and larger long-term deformations owing to the high stress in concrete, which will cause larger creep deformations (Pilakoutas et al., 2011).

Table 2 Overview of existing codes/guides
\begin{tabular}{|l|l|}
\hline Organisation & Year \\
\hline $\begin{array}{l}\text { IStructE - Interim guidance on the design of } \\
\text { reinforced concrete structures using fibre composite } \\
\text { reinforcement (IStructE, 1999). }\end{array}$ & \\
\hline $\begin{array}{l}\text { CSA S806-02 - Design and construction of building } \\
\text { components with fiber-reinforced polymers (CSA, }\end{array}$ & 2002 \\
2002). & \\
\hline ACI 440.1R-06 - Guide for the design and & 2006 \\
\hline
\end{tabular}


construction of structural concrete reinforced with Fiber-Reinforced Polymer (FRP) bars (ACI, 2015).

CNR DT 206/2006 - Guide for the design and 2006 construction of concrete structures reinforced with fiber-reinforced polymer bars (CNR, 2006).

ISIS Canada Design Manual No.3 - Reinforcing 2006 Concrete Structures with Fibre-Reinforced Polymers (ISIS Canada, 2007).

\begin{tabular}{l|l|l}
\hline fib TG 9.3 - Frp reinforcement for rc structures (fib - 2007 & 2007 .
\end{tabular} TG 9.3, 2007).

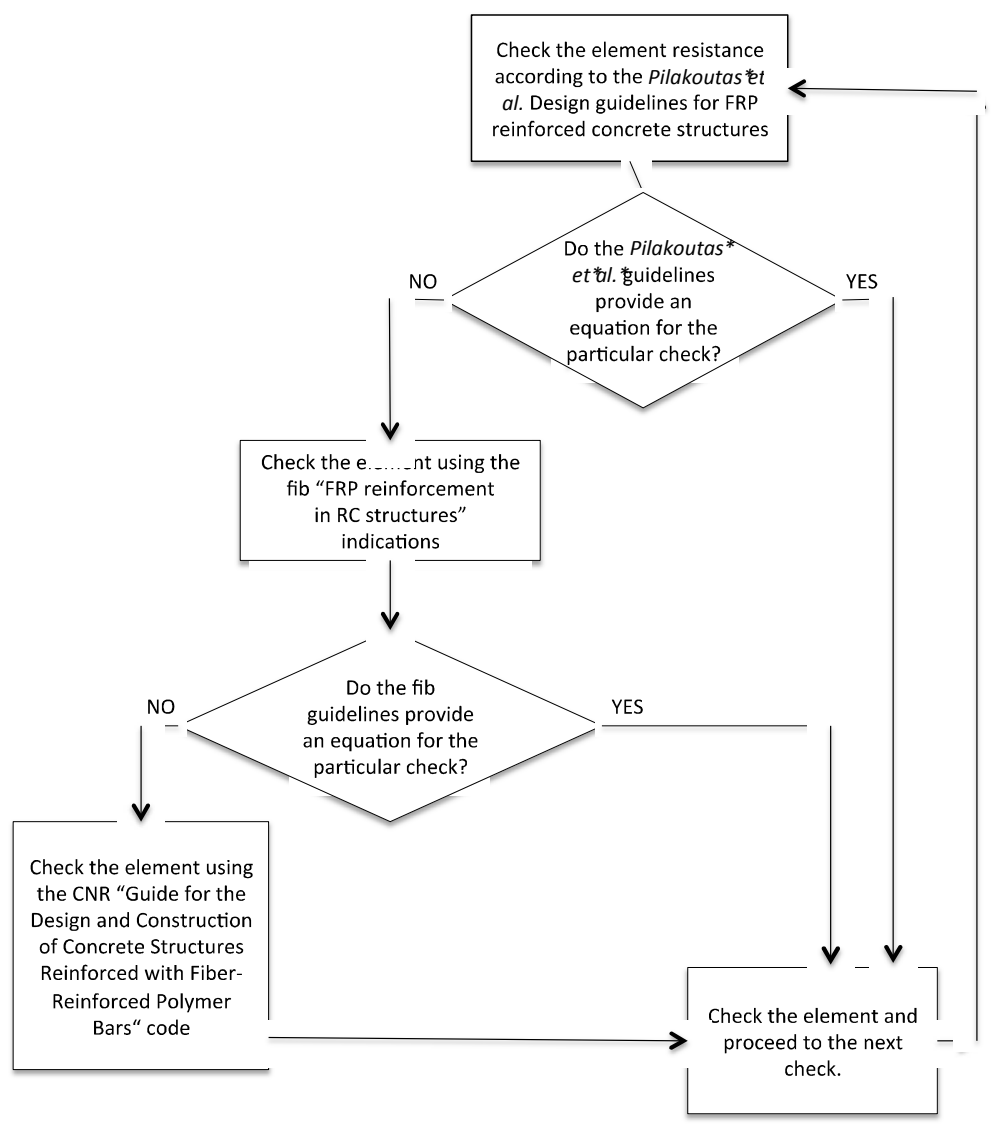

109

110 Figure 2. Design steps diagram according to the modified Eurocode approach

$111 \rho_{f}=\frac{A_{f}}{b d}$

112 Different codes suggest different equations to calculate the balanced reinforcement ratio ofb

113 and the FRP reinforcement ratio of. Unlike steel reinforcement, FRP bars do not show a ductile

114 failure, as shown in Figure 4, and designing for failure due to concrete crushing would generally

115 be the favoured choice. However, this means that only a small portion of the FRP rebars'

116 strength is used and the potential of the material is not fully utilised. The various codes provide 
117 different equations to calculate the balanced reinforcement ratio, based on the internal force

118 equilibrium and on the mechanical properties of the materials

119

120

$\rho_{f b}=0.85 \beta_{1} \frac{f_{c}^{\prime}}{f_{f u}} \frac{E_{f} \varepsilon_{c u}}{E_{f} \varepsilon_{c u}+f_{f u}}$

121

$\rho_{f b}=\alpha_{1} \beta_{1} \frac{\phi_{c}}{\phi_{f}} \frac{f_{c}^{\prime}}{f_{f r p}}\left(\frac{\varepsilon_{c u}}{\varepsilon_{c u}+\varepsilon_{f r p}}\right)$

122

$\rho_{f b}=0.81 \frac{\left(f_{c k}+8\right) \varepsilon_{c u}}{f_{f k}\left(\frac{f_{f k}}{E_{f k}} \varepsilon_{c u}\right)}$

123

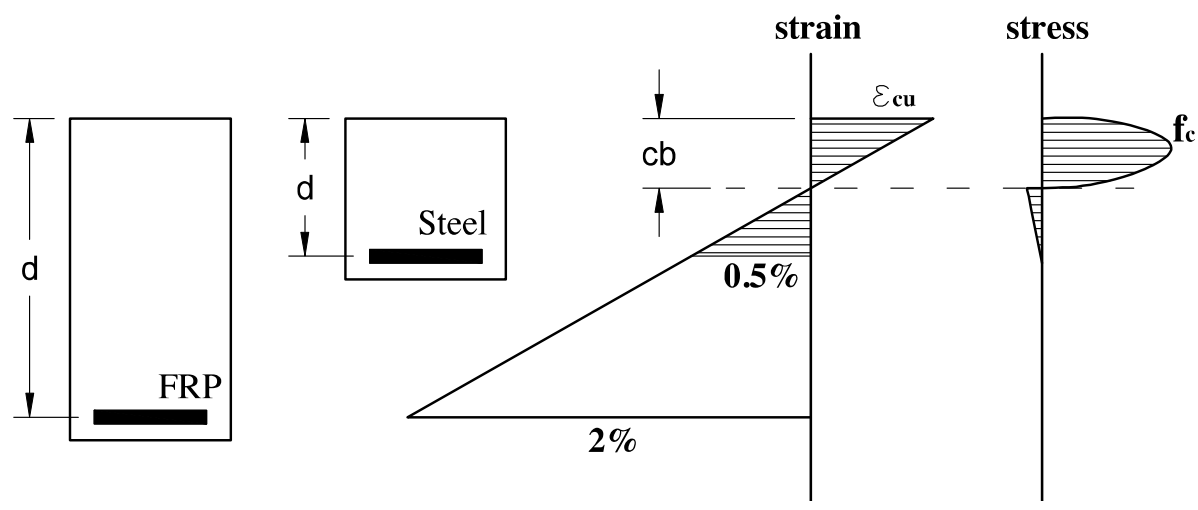

124 Figure 3. Strain distribution for FRP and steel RC balanced section

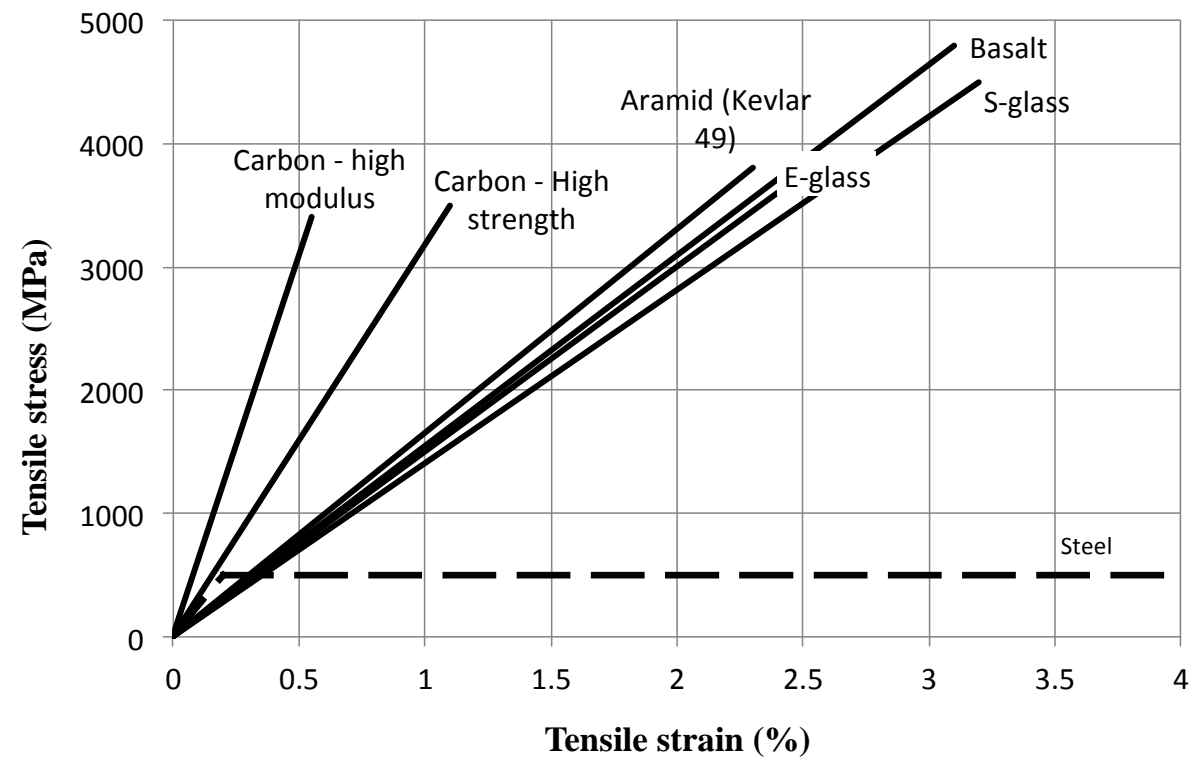

Figure 4. Stress-strain curves of typical reinforcing fibres 
127 The American Concrete Institute $(\mathrm{ACl})$ code recommends Equation 2, and a similar equation is proposed by the Canadian Standards Association (CSA) (Equation 3). Both codes replace the non-linear stress distribution with an equivalent rectangular stress block. Using a similar approach to Eurocode 2 (BS EN 1992-1-1:2004; BSI, 2004), Pilakoutas et al. (2002) proposed

131 Equation 4 for FRP beams. The equation takes into account the material variability of concrete 132 and, to avoid a premature failure, provides higher values of $\mathrm{pfb}$, compared to Equations 2 and 3.

\subsection{Moment resistance of FRP RC elements}

134 Fibre-reinforced polymer RC members in flexure can be designed by checking that the nominal flexural strength $(\mathrm{Mn})$, multiplied by a factor of safety due to the brittle type of failure, exceeds the factored moment (Mu). From ACl 4401r-06 (ACl, 2006)

$137 \phi M_{n} \geq M_{u}$

138 Different codes give different values for $\varphi$, all based on the values of of and $\rho f b$. The ACI, CSA 139 and fib provide Equations 6, 7 and 8, respectively, to calculate the ultimate moment resistance 140 of an over-reinforced FRP RC member.

$141 \quad M_{n}=A_{f} f_{f}\left(d-\frac{a}{2}\right)$

$142 \quad M_{n}=C\left(d-\frac{\beta_{1} c}{2}\right)$

$143 \quad M_{n}=\eta f_{c d} b d^{2}(\lambda \xi)\left(1-\frac{\lambda \xi}{2}\right)$

144 In Eq. 6 the stress distribution is approximated with a rectangular stress block, where a is the 145 depth of the stress block:

$146 a=\left(\frac{A_{f} f_{f}}{0.85 f^{\prime}{ }_{c} b}\right)$

147 The stress level in the FRP can be calculated as follows

$148 f_{f}=E_{f} \varepsilon_{c u} \frac{\beta_{1} d-a}{a}$

149 The CSA uses a similar approach with Equation 7, where the moment resistance of the section 150 can be determined considering the force equilibrium: 
152 where $c$ is the neutral axis depth and $\phi_{c}$ the material factor for concrete. The product $\beta_{1} c$ is the 153 depth of the stress block used to approximate the stress distribution, which leads to similar 154 results to Eq. 6. In Eq. 8 proposed in the fib report (fib - TG 9.3 (fib, 2007)), $\lambda$ and $\eta$ are factors 155 that take into account the strength of concrete. The ratio between the neutral axis depth and the 156 cross section effective depth $\xi$, can be calculated as follows

$157 \quad \xi=\frac{x}{d}=\frac{\varepsilon_{c u}}{\varepsilon_{f}+\varepsilon_{c u}}$

$158 \varepsilon_{f}=\frac{-\varepsilon_{c u}+\sqrt{\varepsilon_{c u}^{2}+\frac{4 \eta \alpha_{c c} f_{c k} \lambda \varepsilon_{c u}}{\gamma_{c} \rho_{f} E_{f}}}}{2}$

159 The stress block used when the failure is provoked by concrete crushing is not applicable when 160 designing an under-reinforced element and the failure is induced by the FRP rupture. In this 161 case the concrete compressive strain at failure is unknown and an approximated equivalent 162 stress block is needed. The $\mathrm{ACl}$ code proposes Eq. 14 to calculate the nominal moment 163 capacity.

$164 \quad M_{n}=A_{f} f_{f u}\left(d-\frac{\beta_{1} c}{2}\right)$

165 To avoid a complex analysis with multiple unknowns it is possible and conservative to assume 166 that the maximum concrete strain is attained, using Equation 15

$167 M_{n}=A_{f} f_{f u}\left(d-\frac{\beta_{1} c_{b}}{2}\right)$

$168 \quad c_{b}=\left(\frac{\varepsilon_{c u}}{\varepsilon_{c u}+\varepsilon_{f u}}\right) d$

169 where $c_{b}$ is the depth of neutral axis at balanced failure condition, and can be calculated as per 170 Eq. 16. A similar equation is proposed by the CSA Standard. Otherwise, it is necessary to 171 determine the concrete compressive strain, which can be done carrying out an iterative 172 procedure as suggested in the fib document (fib - TG 9.3 (fib, 2007)) 
$173 \quad \xi=\frac{x}{d}=\frac{\varepsilon_{c u}}{\varepsilon_{f}+\varepsilon_{c u}}$

$174 \quad F_{C}=b d \xi \frac{\int_{0}^{\varepsilon_{0}} f_{c d} d \varepsilon_{c}}{\varepsilon_{c}}=\frac{A_{f} f_{f k}}{\gamma_{f}}=F_{T}$

$175 M_{n}=\frac{A_{f} f_{f k}}{\gamma_{f}}\left(1-\frac{\xi}{2}\right)$

\section{$176 \quad$ 2.4. Reduction factors}

177 When considering the influence of durability on the design, the international codes propose

178 environmental effect factors that reduce the strength of the FRP reinforcement. If refining the 179 criteria used to reduce the material strength, taking into consideration factors as moisture, 180 temperature, time and presence of alkali, a more accurate and less conservative result can be 181 achieved. A comparison of the reduction factors proposed by the existing guidelines is 182 presented in Tables 3 and 4. The fib Bulletin 40 (fib - TG 9.3 (fib, 2007)) proposes a 183 methodology to determine an environmental factor as a function of the environmental conditions 184 chosen by the designer. This provides a factor that has to be considered in the design strength 185 Equation 20 ( fib - TG 9.3 (fib, 2007))

$186 f_{f d}=\frac{f_{f k 0}}{\eta_{e n v, f}}$

187 The environmental strength reduction factor $\eta_{\text {env }}$ relates experimental factors and factors 188 depending on the designer's judgement on the type of environment (e.g. moisture percentage). 189 This approach brings benefit to the design, providing an accurate level of safety. It does not 190 imply that the suggested factor would necessarily be less restrictive than those presented in 191 Tables 3 and 4. In fact, as shown in the fib bulletin (fib - TG 9.3 (fib, 2007)) and in Stuart (2014) 192 the environ- mental strength reduction factor can reduce the bar strength by up to $40 \%$.

193 Table 3 Reduction factors for tensile strength at ULS

\begin{tabular}{|l|l|l|l|}
\hline Material & IStructE (1999) & ACI 440.1R-06 & CSA S806-02 \\
& & & \\
\hline ULS environment & E-glass: $1 / 3.6$ & GFRP: $0.8-0.8$ & GFRP: 0.5 \\
& Aramid: $1 / 2.2$ & AFRP:0.8-0.9 & AFRP: 0.6 \\
& Carbon: $1 / 1.8$ & CFRP: 0.9-1.0 & CFRP: 0.75 \\
\hline ULS long term & GFRP: 0.3 & - & - \\
\hline
\end{tabular}


194

195

196

197

198

199

200

201

202

203

204

205

206

207

208

209

210

211

212

213
Table 4. Reduction factors for tensile strength at SLS

\begin{tabular}{|l|l|l|l|}
\hline Material & IStructE (1999) & ACI 440.1R-06 & CSA S806-02 \\
\hline SLS environment & GFRP: 0.3 & GFRP: 0.39-0.52 & GFRP: 0.25 \\
& AFRP: 0.5 & AFRP: 0.44-0.59 & AFRP: 0.35 \\
& CFRP: 0.6 & CFRP: 0.50-0.65 & CFRP: 0.65 \\
\hline SLS long term & - & GFRP: 0.14-0.16 & (pre/post tension) \\
& & AFRP: 0.24-0.27 & GFRP: 0.25-0.30 \\
& & CFRP: 0.44-0.50 & AFRP: 0.35-0.40 \\
& & & CFRP: 0.65-0.70 \\
\hline
\end{tabular}

\subsection{Serviceability Limit States}

The principles behind the verification of SLS for steel RC elements can be applied to FRP RC elements (fib - TG 9.3, (fib, 2007)), therefore the provisions in the existing codes of practice can be taken and modified to allow for differences in both short and long-term properties between steel and FRP reinforcement. The stress in concrete, at service load levels, can reach 80 to $100 \%$ of the peak stress (Cosenza et al., 1997). This leads to limit the working stress of the concrete and results in a non-economical use of the FRP reinforcement and an unnecessary increase in flexural capacity. Therefore, more research should investigate the SLS concrete stress limits for FRP RC to maximise the efficiency of the reinforcement.

\subsubsection{Deflections}

Considering two RC members under similar conditions, loading, dimensions, area of reinforcement and with different reinforcement material, steel and FRP, the latter would develop larger deformations due to the lower modulus of elasticity of the (non-carbon) FRP bars. Therefore, even considering that glass-fibre-reinforced polymer (GFRP) bars have a similar price to stainless steel ones, it is more expensive to maintain the same deflection limit when using FRP products (Balafas and Burgoyne, 2012). The Eurocode 2 formula for the calculation 
214 of short- and long-term deflection for steel RC can be used for FRP-reinforced members, being 215 opportunely adapted using the factors to allow for the tension stiffening effect, duration of the 216 load and bond (CNR, 2006). ACl 440.1R-06 (ACl, 2006) provides equations to calculate the 217 effective moment of inertia that can be used in the deflection analysis of steel-reinforced 218 concrete beams (Branson, 1968) and opportunely adapted to be used for FRP-reinforced 219 members. The CSA recommends the use of the transformed moment of inertia It to calculate 220 the immediate deflection (CSA, 2002). If the service moment exceeds the cracking moment, 221 CSA A23.3-04 recommends the use of the effective moment of inertia, le, which is related to the 222 transformed moment of inertia and the moment of inertia for a cracked concrete cross-section 223 (CSA, 2004).

224

\subsubsection{Crack width}

225

The theory used for steel RC can be applied to FRP RC and the same equations can be used, 226 with opportune changes of coefficients and crack width limit, to take into account the different material and the different bond conditions.

228 It can be seem in Table 5 that the crack width limitations for FRP RC elements are more relaxed 229 than for steel ones. This is because FRP bars are corrosion resistant and therefore less severe 230 limits can be adopted $(\mathrm{ACl}, 2006)$. In FRP-reinforced structures, the appearance, rather than 231 durability, governs the crack width.

\subsection{Design case studies}

\subsubsection{Design approach}

234 In the following, the results of the design of three different slab systems with spans commonly seen in practice are presented. These will also be compared with a traditional steel reinforcement solution designed to the Eurocode. For the comparative design studies presented in this work, glass FRP bars were chosen for all of the designs; even if they did not match the stiffness and ultimate strength properties of carbon fibre bars size for size, their competitive price makes them the most popular type on the market. For the design of the slabs, as recommended by the $\mathrm{ACl}$ guideline (see Section 2 for overview of existing codes), an overreinforced condition was preferred over a balanced-reinforced condition. For each slab type the

242 first design was carried out using the modified European approach to work out the slab depth

243 and required reinforcement. Once the properties of the slab were fixed, the design was checked 
244 using the American and Canadian codes. To establish the loads considered for the design, 245 precedence was given to the modified Eurocode approach, and the loads and safety coefficients 246 recommended by the Eurocodes were used to calculate the factored loads on the slabs. The fire 247 requirements were not considered in this study, and it was assumed that the elements designed 248 would be able to carry the loads under fire through an alternative mechanism and load path.

249 The following slabs will now be analysed

250 - One-way RC spanning slab for a multi-storey car park using normal weight (NW) concrete

$251 \quad-\quad \square$ Two-way RC spanning slab for a swimming pool roof using NW concrete

252 - Two-way RC spanning flat slab for a medical facility using light-weight (LW) concrete

253 Table 5. Crack width limitations for FRP and steel RC elements

\begin{tabular}{|l|l|l|l|l|}
\hline Code & Eurocode 2 & CNR (2006) & \multicolumn{2}{l|}{$\begin{array}{l}\text { ACI 440.1R (2006) / } \\
\text { CSA (1996) }\end{array}$} \\
\hline Material & Steel & FRP & FRP & \\
\hline Exposure & Normal & - & Interior & Exterior \\
\hline $\mathrm{w}_{\max }$ & $0.3 \mathrm{~mm}$ & $0.5 \mathrm{~mm}$ & $0.7 \mathrm{~mm}$ & $0.5 \mathrm{~mm}$ \\
\hline
\end{tabular}

254

255

2.6.2.Material properties, Geometry and Loads

256 Tables 6-9 present the properties of the materials used in the models of the slabs. The depth of

257 the slabs modelled in Abaqus was obtained from the design in accordance with the European

258 approach. The first slab analysed is a one-way NW RC spanning slab for a multi-storey car

259 park, simply supported over $7.5 \mathrm{~m}$, as shown in Figure 5 . The environment is considered to be 260 aggressive, classified by BS EN 206:2013 (BSI, 2013) as XD3, hence would require a $40 \mathrm{~mm}$ 261 cover for traditional steel reinforcement. The second slab analysed in this study is part of a 262 swimming pool roof, assumed to be sup- ported by beams in both directions, as shown in Figure

263 6. The environmental condition considered is wet and rarely dry, and it is classified by BS EN 264 206:2013 (BSI, 2013) with the label XD2, which requires a minimum concrete cover of $35 \mathrm{~mm}$. 265 This is a requirement due to environmental conditions, and hence it applies to the steel 266 reinforcement only. The third slab presented in this study is a flat slab, with dimensions as 267 shown in Figure 7. It is assumed to be an internal panel of a larger structure, where slabs are 268 cast in situ and are continuous along the structure. Tables 10-12 show the loads for each slab 269 type.

270 Table 6. Mechanical properties of concrete 


\begin{tabular}{|l|l|l|l|}
\hline Element & $\begin{array}{l}\text { One-way } \\
\text { slab }\end{array}$ & $\begin{array}{l}\text { Two-way } \\
\text { slab }\end{array}$ & $\begin{array}{l}\text { Flat } \\
\text { slab }\end{array}$ \\
\hline $\mathrm{f}_{\mathrm{ck}, \mathrm{cube}}[\mathrm{MPa}]$ & 45 & 37 & 28 \\
\hline $\mathrm{f}_{\mathrm{ck}, \mathrm{cvl}}[\mathrm{MPa}]$ & 35 & 30 & 25 \\
\hline $\mathrm{f}_{\mathrm{cm}}[\mathrm{MPa}]$ & 43 & 38 & 33 \\
\hline $\mathrm{f}_{\mathrm{ctm}}[\mathrm{MPa}]$ & 3.21 & 2.90 & 2.75 \\
\hline $\mathrm{f}_{\mathrm{ctk}}[\mathrm{MPa}]$ & 2.25 & 2.03 & 1.80 \\
\hline $\mathrm{f}_{\mathrm{cd}}[\mathrm{MPa}]$ & 19.83 & 17 & 14.73 \\
\hline $\mathrm{E}_{\mathrm{cm}}[\mathrm{GPa}]$ & 34.077 & 32.837 & 28.042 \\
\hline $\mathrm{v}$ & 0.2 & 0.2 & 0.2 \\
\hline
\end{tabular}

271

272 Table7. Mechanical properties of steel reinforcement

\begin{tabular}{|l|l|l|l|l|}
\hline $\begin{array}{l}\mathrm{f}_{\mathrm{yk}} \\
{[\mathrm{MPa}]}\end{array}$ & $\begin{array}{l}\mathrm{f}_{\mathrm{yd}} \\
{[\mathrm{MPa}]}\end{array}$ & $\begin{array}{l}\mathrm{f}_{\mathrm{cd}} \\
{[\mathrm{MPa}]}\end{array}$ & $\begin{array}{l}\mathrm{E}_{\mathrm{s}} \\
{[\mathrm{MPa}]}\end{array}$ & $\varepsilon_{\mathrm{y}}[\%]$ \\
\hline 500 & 434.8 & 1.15 & $\begin{array}{l}21000 \\
0\end{array}$ & 0.2 \\
\hline
\end{tabular}

274 Table 8. Mechanical properties of FRP reinforcement

\begin{tabular}{|l|l|l|}
\hline $\begin{array}{l}\mathrm{f}_{\mathrm{f}} \\
{[\mathrm{MPa}]}\end{array}$ & $\begin{array}{l}\mathrm{E}_{\mathrm{cm}} \\
{[\mathrm{MPa}]}\end{array}$ & $\begin{array}{l}\varepsilon_{\mathrm{f}} \\
{[\%} \\
]\end{array}$ \\
\hline 775 & 45000 & 1.7 \\
\hline
\end{tabular}

275

276 Table 9. Material and load factors (BSI, 2002; 2004 and fib, 2007)

\begin{tabular}{l|l}
\hline Load factors & Material factors (EN 2)
\end{tabular}

\begin{tabular}{|l|l|l|l|l|}
\hline$\gamma_{\mathrm{G}}$ & $\gamma_{\mathrm{Q}}$ & $\gamma_{\mathrm{C}}$ & $\gamma_{\mathrm{S}}$ & $\gamma_{\mathrm{f}}$ \\
\hline 1.35 & 1.5 & 1.5 & 1.15 & 1.25 \\
\hline
\end{tabular}

277

278

Q1
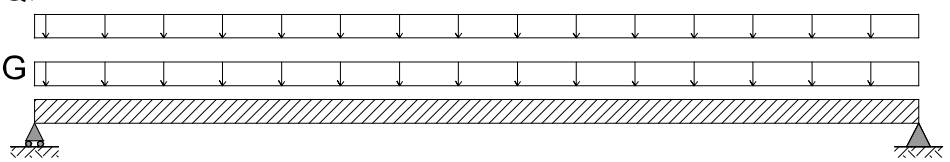

279

7500

280 Figure 5. One-way GFRP slab: elevation (dimensions: $\mathrm{mm}$ ) 

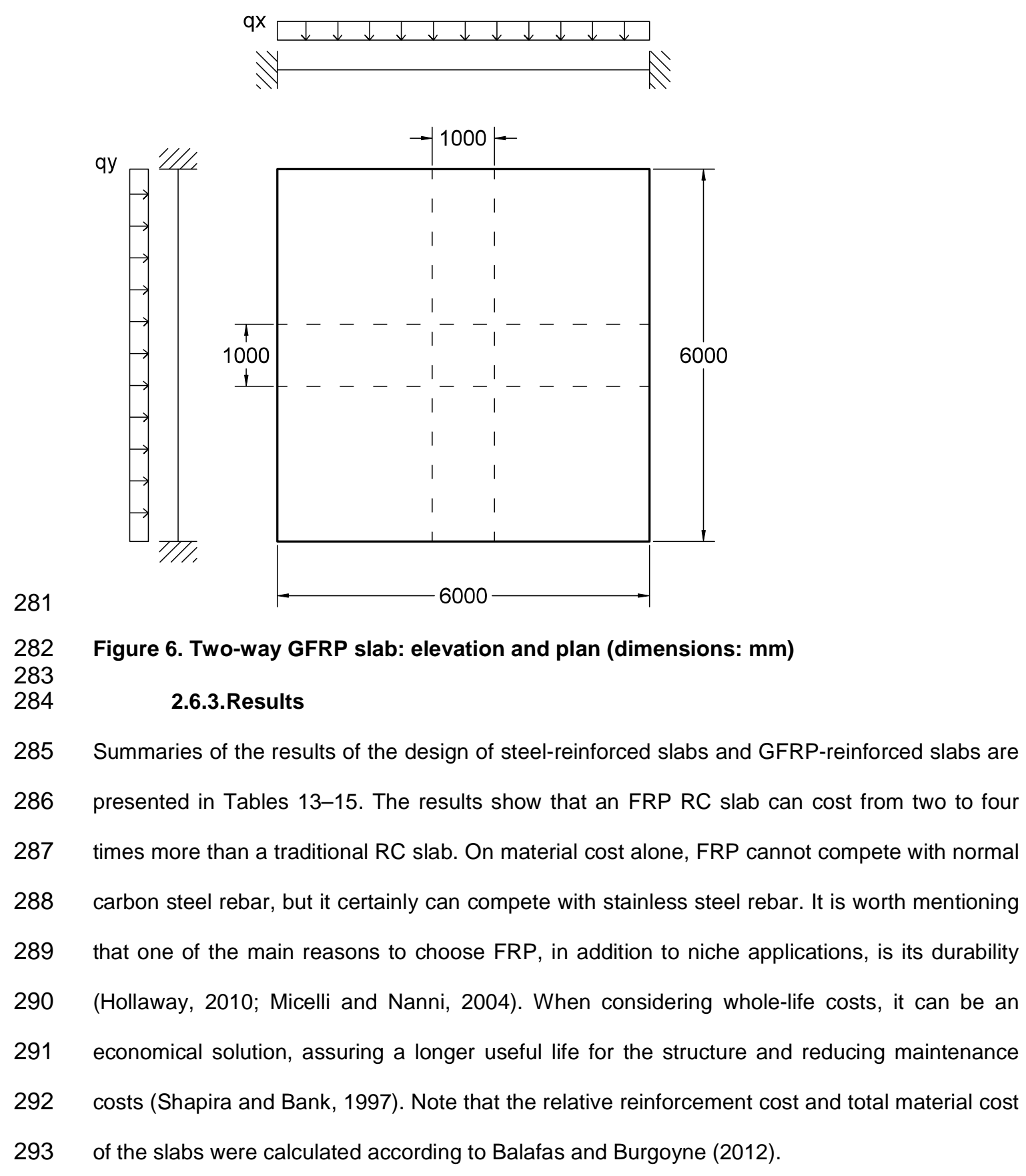


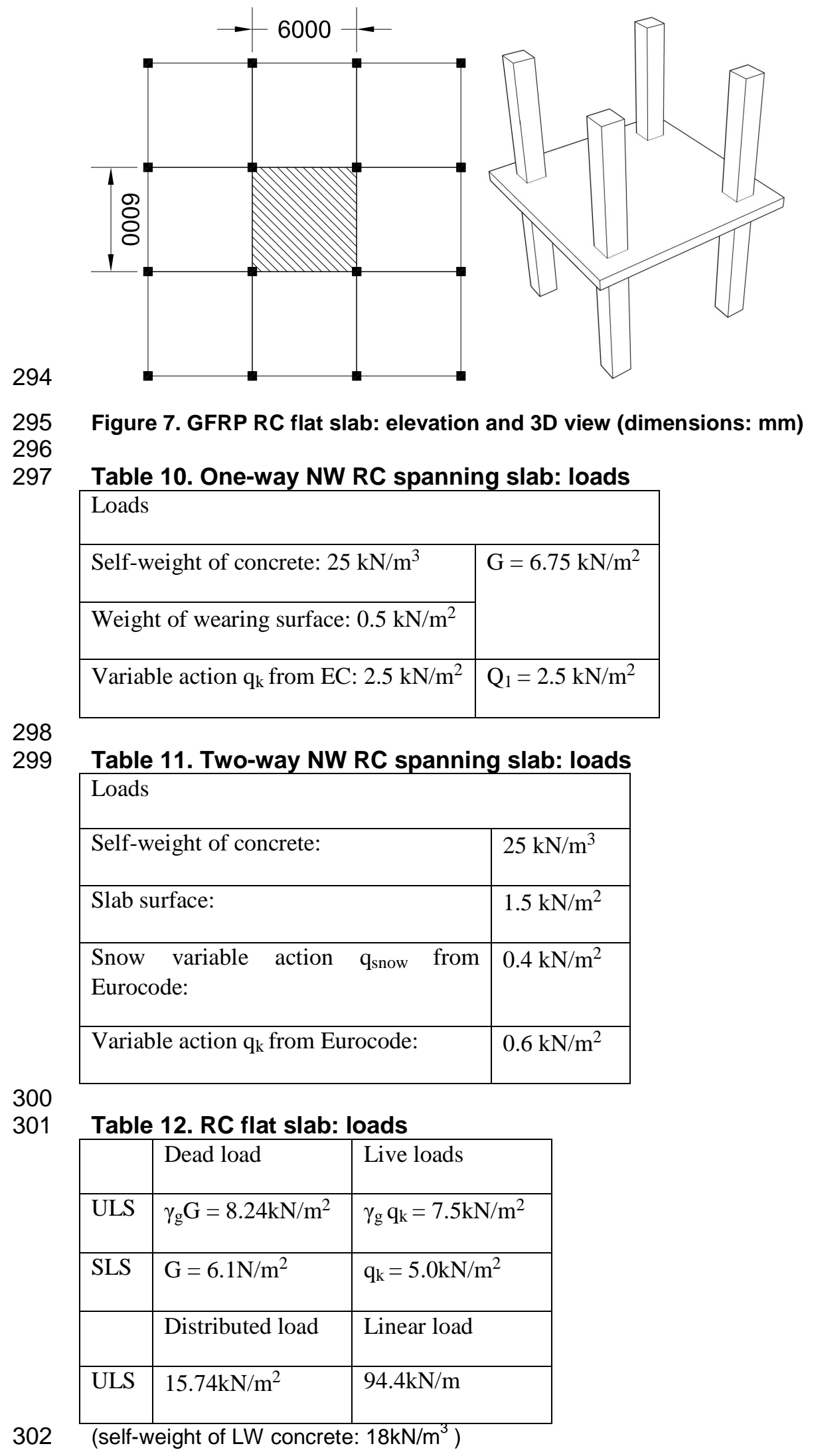




\section{Overview of FE modelling of RC}

\subsection{Model validation}

305 The modelling was undertaken using the commercial software Abaqus version 6.12. The model

306 had been previously validated against several experimental studies, including the modelling of

307 traditional steel RC beams and slabs. For brevity, one of the validation studies will be discussed

308 here, further details and additional validation studies can be found in Stuart (2014). One of the

309 validation models simulated the tests conducted at the Universit de Sherbrooke (Quebec,

310 Canada) by Benmokrane et al. (2004) on a GFRP RC one-way slab denoted in the experiment

311 as specimen S-GGB. A schematic drawing of the test set-up is shown in Figure 8, and a plan

312 view of the FE model is provided in Figure 9. The markers used in Figures 10 and 11 show

313 where the concrete reached its maximum compressive strength. The model simulated correctly

314 the mode of failure by concrete crushing. Some discrepancies of the results can be accepted

315 due to reasonable uncertainties related to the material properties, degree of bond (the rebar

316 was assumed to be fully bonded), and the influence of the supports used in the tests. The

317 nature of bond between the rebar and the concrete can be influential in determining the pre-

318 crack stiffness of the concrete. In practice, it is common to assume full bond between rebar and

319 concrete when modelling, however, this ignores the effect of bond slip. Any reduction in bond

320 can result in a less stiff response in the member. Typically, where flexural elements have been

321 modelled in FE using full bond assumptions, the pre-crack early behaviour of the members may

322 be in excess of $30 \%$ stiffer than the experimental case (Genikomsou and Polak, 2015; Jendele

323 and Cervenka, 2006). For the case of FRP rebar, it is likely that the effect of bond slip may be

324 more pronounced than for steel rebar in the pre-crack regime, depending on the type of rebar

325 profile, namely, ribbed or smooth, and so on. Recently a number of bond-slip models have been

326 proposed for FRP rebar which offer improved prediction of the early pre-cracking behaviour; a

327 comprehensive review of these can be found in Lin and Zhang (2014). Although the full bond

328 assumption may over-predict stiffness in the early pre-crack regime, studies have shown this to

329 be less significant in the post-cracking regime. Rafi et al. (2007) conducted a series of FE

330 simulations of FRP-reinforced beams collated from various different experiments, in all cases a

331 full bond assumption was adopted. In each case the FE model was shown to provide an

332 accurate prediction of overall member behaviour; a similar conclusion can be drawn from 
333 Figures 10 and 11. Based on the aforementioned, in the current study, a full bond assumption

334 was adopted for expediency.

335 Table 13. One-way GFRP RC slabs: comparison

\begin{tabular}{|c|c|c|c|c|}
\hline 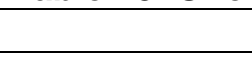 & Steel & GFRP & & \\
\hline Code & Eurocode & Eurocodes & $\mathrm{ACl}$ & CSA \\
\hline Thickness & $280 \mathrm{~mm}$ & \multicolumn{3}{|l|}{$275 \mathrm{~mm}$} \\
\hline $\begin{array}{l}\text { Longitudinal } \\
\text { reinforcement }\end{array}$ & ф16@200mm & \multicolumn{3}{|l|}{ ф24@100mm } \\
\hline MRd & $100 \mathrm{kNm}$ & $302 \mathrm{kNm}$ & $223 \mathrm{kNm}$ & $249 \mathrm{kNm}$ \\
\hline$\sigma$ GFRP,fail & 490MPa & $321 \mathrm{MPa}$ & $361 \mathrm{MPa}$ & $517 \mathrm{MPa}$ \\
\hline $\begin{array}{l}\text { Admissible } \\
\text { stress ULS }\end{array}$ & - & $332 \mathrm{MPa}$ & $448 \mathrm{MPa}$ & $775 \mathrm{MPa}$ \\
\hline$\sigma \mathrm{GFRP}, \mathrm{SLS}$ & - & $79 \mathrm{MPa}$ & $70 \mathrm{MPa}$ & $70 \mathrm{MPa}$ \\
\hline $\begin{array}{l}\text { Admissible } \\
\text { stress SLS }\end{array}$ & - & $233 \mathrm{MPa}$ & $155 \mathrm{MPa}$ & $233 \mathrm{MPa}$ \\
\hline$\Delta$ & - & $35.5 \mathrm{~mm}$ & $38.0 \mathrm{~mm}$ & $39.6 \mathrm{~mm}$ \\
\hline$\omega c r a c k s$ & - & $0.303 \mathrm{~mm}$ & $0.300 \mathrm{~mm}$ & 0.257 \\
\hline wcracks,MAX & - & $0.3 \mathrm{~mm}$ & $0.5 \mathrm{~mm}$ & $0.5 \mathrm{~mm}$ \\
\hline $\begin{array}{l}\text { Design } \\
\text { governed by: }\end{array}$ & Deflection & $\begin{array}{l}\text { Reinforcement: } \\
\text { over-reinforced. } \\
\text { Concrete: } \\
\text { deflection }\end{array}$ & Deflection & Deflection \\
\hline $\begin{array}{l}\text { Longitudinal } \\
\text { reinf. cost }\end{array}$ & $£ 210$ & \multicolumn{3}{|l|}{$£ 780$} \\
\hline $\begin{array}{l}\text { Total } \\
\text { reinforcement } \\
\text { cost }\end{array}$ & $£ 312$ & \multicolumn{3}{|l|}{$£ 955$} \\
\hline Total cost & $£ 580$ & \multicolumn{3}{|l|}{$£ 1326$} \\
\hline
\end{tabular}

336

337

Table 14. Two-way GFRP RC slabs: comparison

\begin{tabular}{|c|c|c|c|c|}
\hline (1) & Steel & \multicolumn{3}{|l|}{ GFRP } \\
\hline Code & Eurocode & Eurocodes & $\mathrm{ACl}$ & CSA \\
\hline Thickness & $200 \mathrm{~mm}$ & \multicolumn{3}{|l|}{$150 \mathrm{~mm}$} \\
\hline $\begin{array}{l}\text { Longitudinal } \\
\text { reinforcement }\end{array}$ & $\phi 12 @ 200 \mathrm{~mm}$ & \multicolumn{3}{|c|}{ ф20@200mm } \\
\hline MRd & $35 \mathrm{kNm} / \mathrm{m}$ & $41 \mathrm{kNm} / \mathrm{m}$ & $31 \mathrm{kNm} / \mathrm{m}$ & $28 \mathrm{kNm} / \mathrm{m}$ \\
\hline$\sigma$ GFRP,fail & $222 \mathrm{MPa}$ & $320 \mathrm{MPa}$ & $358 \mathrm{MPa}$ & $425 \mathrm{MPa}$ \\
\hline $\begin{array}{l}\text { Admissible } \\
\text { stress ULS }\end{array}$ & - & $339 \mathrm{MPa}$ & $448 \mathrm{MPa}$ & $775 \mathrm{MPa}$ \\
\hline$\sigma$ GFRP,SLS & - & $75 \mathrm{MPa}$ & $67 \mathrm{MPa}$ & $67 \mathrm{MPa}$ \\
\hline $\begin{array}{l}\text { Admissible } \\
\text { stress SLS }\end{array}$ & - & $233 \mathrm{MPa}$ & $155 \mathrm{MPa}$ & $231 \mathrm{MPa}$ \\
\hline$\Delta$ & - & $1.5 \mathrm{~mm}$ & $2.0 \mathrm{~mm}$ & $2.0 \mathrm{~mm}$ \\
\hline$\omega \mathrm{cracks}$ & - & Uncracked & Uncracked & Uncracked \\
\hline $\begin{array}{l}\text { Design } \\
\text { governed by: }\end{array}$ & Deflection & \multicolumn{3}{|c|}{$\begin{array}{l}\text { Depth of concrete governed by deflection. Amount } \\
\text { of reinforcement, governed by pfb }\end{array}$} \\
\hline $\begin{array}{l}\text { Total } \\
\text { reinforcement }\end{array}$ & $£ 456$ & \multicolumn{3}{|l|}{$£ 2080$} \\
\hline
\end{tabular}




\begin{tabular}{|l|l|l|}
\hline cost & & \\
\hline Total cost & $£ 982$ & $£ 2469$ \\
\hline
\end{tabular}

Table 15. GFRP RC flat slabs: comparison

\begin{tabular}{|c|c|c|c|c|}
\hline & Steel & GFRP & & \\
\hline Code & Eurocode & Eurocodes & $\mathrm{ACl}$ & CSA \\
\hline Thickness & $200 \mathrm{~mm}$ & $275 \mathrm{~mm}$ & & \\
\hline Longitudinal & ф10@150mm & ф18@100mm & & \\
\hline & $\phi 10 @ 100 \mathrm{~mm}$ & $\phi 20 @ 100 \mathrm{~mm}$ & & \\
\hline Longitudinal & ф10@150mm & ф20@150mm & & \\
\hline & ф10@150mm & ф18@150mm & & \\
\hline & ф12@100mm & \$20@100mm & & \\
\hline $\begin{array}{l}\text { MRd+ } \\
\text { midspan }\end{array}$ & $131 \mathrm{kNm} / \mathrm{m}$ & $178 \mathrm{kNm} / \mathrm{m}$ & $132 \mathrm{kNm} / \mathrm{m}$ & $175 \mathrm{kNm} / \mathrm{m}$ \\
\hline $\begin{array}{l}\text { MRd-,MRd+ @ } \\
\text { supports }\end{array}$ & $142 \mathrm{kNm} / \mathrm{m}$ & $187 \mathrm{kNm} / \mathrm{m}$ & $139 \mathrm{kNm} / \mathrm{m}$ & $185 \mathrm{kNm} / \mathrm{m}$ \\
\hline $\begin{array}{l}\sigma \text { GFRP,fail @ } \\
\text { midspan }\end{array}$ & $163 \mathrm{MPa}$ & $313 \mathrm{MPa}$ & $351 \mathrm{MPa}$ & $408 \mathrm{MPa}$ \\
\hline $\begin{array}{l}\text { oGFRP,fail @ } \\
\text { supports }\end{array}$ & $212 \mathrm{MPa}$ & $357 \mathrm{MPa}$ & $399 \mathrm{MPa}$ & $465 \mathrm{MPa}$ \\
\hline $\begin{array}{l}\text { Admissible } \\
\text { stress ULS }\end{array}$ & - & $620 \mathrm{MPa}$ & $512 \mathrm{MPa}$ & $775 \mathrm{MPa}$ \\
\hline $\begin{array}{l}\text { бGFRP,SLS } \\
@ \text { midspan }\end{array}$ & - & $48.9 \mathrm{MPa}$ & $50.5 \mathrm{MPa}$ & $49.8 \mathrm{MPa}$ \\
\hline $\begin{array}{l}\text { бGFRP,SLS } \\
\text { @supports }\end{array}$ & - & $52.5 \mathrm{MPa}$ & $51.5 \mathrm{MPa}$ & $50.7 \mathrm{MPa}$ \\
\hline $\begin{array}{l}\text { Admissible } \\
\text { stress SLS }\end{array}$ & - & $233 \mathrm{MPa}$ & $155 \mathrm{MPa}$ & $233 \mathrm{MPa}$ \\
\hline Shear & - & $42 \mathrm{kN}$ & $88 \mathrm{kN}$ & $88 \mathrm{kN}$ \\
\hline$\Delta$ & - & $4.4-42 \mathrm{~mm}$ & $4.4-56.5 \mathrm{~mm}$ & $4.4-56.5 \mathrm{~mm}$ \\
\hline wcracks,MAX & - & $0.36 \mathrm{~mm}$ & $0.5 \mathrm{~mm}$ & $0.5 \mathrm{~mm}$ \\
\hline $\begin{array}{l}\text { Design } \\
\text { governed by: }\end{array}$ & Deflection & Crack width I & & \\
\hline $\begin{array}{l}\text { Total } \\
\text { reinforcement } \\
\text { cost }\end{array}$ & $£ 2310$ & $£ 8360$ & & \\
\hline Total cost & $£ 2830$ & $£ 8950$ & & \\
\hline
\end{tabular}

343 The constitutive model used in this project is the concrete damaged plasticity (CDP) model. This

344 model was chosen because of its inherent robustness in regard to numerical convergence,

345 particularly where significant non-linear behaviour is in occurrence, (Daud et al., 2017;

346 Genikomsou and Polak, 2015). One of the main advantages of the CDP model is the direct 
347 relation between the parameters that describe the model and their physical interpretation. The 348 recommended values for the parameters describing the CDP model are summarised in Table 349 16. Further background detail on the FE model can be found in Stuart (2014), Kmiecik and 350 Kaminski (2011) and Simulia (2012). Severe convergence difficulties might be caused in models 351 where softening behaviour and stiffness degradation are exhibited. It is possible to solve those 352 convergence difficulties by using a viscoplastic regularisation of the constitutive equations. The 353 CDP model can allow the stresses to be outside the yield surface. The use of the viscoplastic 354 regularisation, adopting a small value for the viscosity parameter $\mu$ compared to the value of the 355 time increment, can significantly improve the rate of convergence of the model without 356 significantly affecting the results. Here $\mu$ represents the relaxation time of the viscoplastic 357 system and is the plastic strain evaluated in the inviscid backbone model (Simulia, 2012). A 358 value of 0.0005 was used, based on the validation study (Stuart, 2014).

359

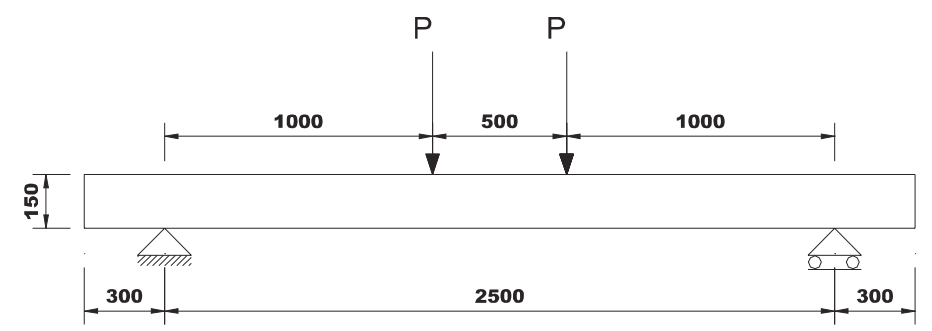

360 Figure 8. One-way GFRP RC slab: test set-up, elevation (dimensions: $\mathbf{m m}$ )

361
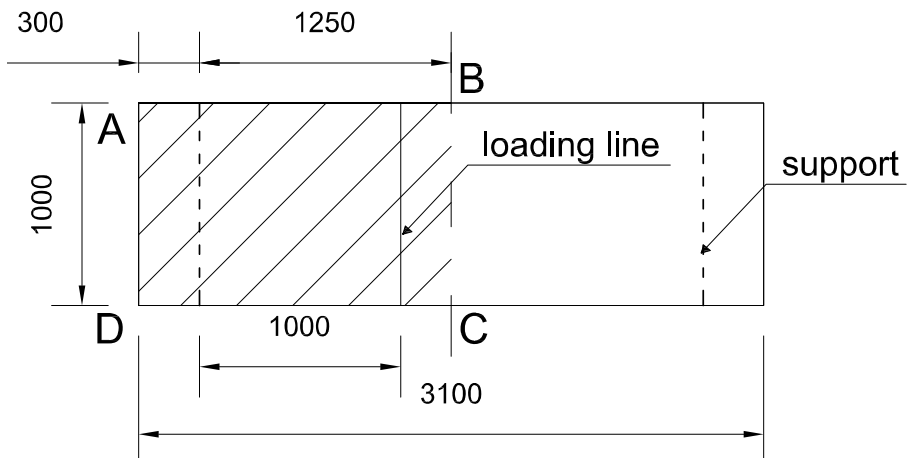

363 Figure 9. One-way GFRP RC slab: FE model (dimensions: mm). Considering the 364 symmetry of the set-up, only the portion highlighted on the left-hand side was modelled 365 in Abaqus 


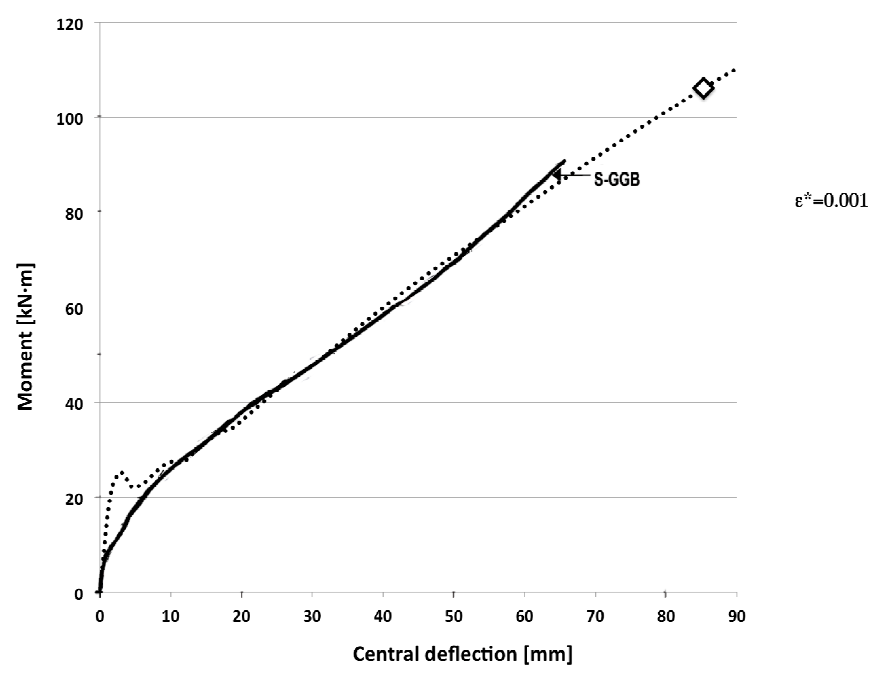

Figure 10. One-way GFRP RC slab: moment-strain curves in the bottom rebar at mid-

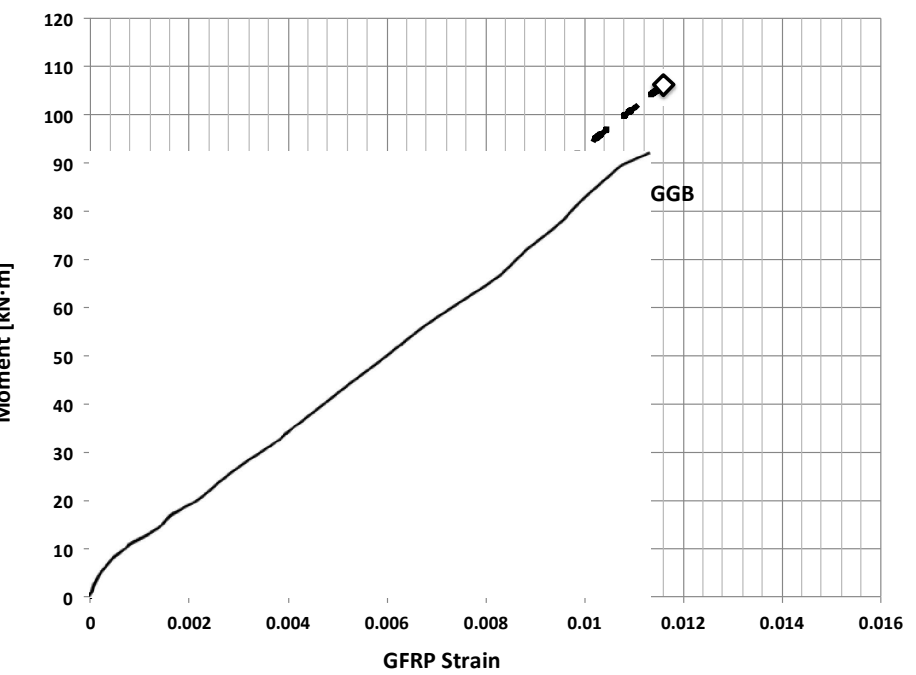
GFRP Strain

Figure 11. One-way GFRP RC slab: load-displacement (at mid-span) curves. Abaqus results compared with experimental results (S-GGB). The marker identifies the point of first onset of concrete failure

\subsubsection{Stress strain relations}

375 In the model, additive strain rate decomposition is assumed:

377 where $\dot{\varepsilon}$ is the total strain rate, and $\dot{\varepsilon}^{e l}$ and $\dot{\varepsilon}^{p l}$ are the elastic and plastic parts of the strain 378 respectively. In the CDP model the inelastic strains are used to draw the stress-strain curve for 379 uniaxial compression, for more information refer to the ABAQUS manual (Simulia, 2012). 
380 To transform the strains, it is necessary to identify the stress for which the material can be

381 considered as non-linearly elastic. As suggested in the Eurocode 2, this point was assumed as

$3820.4 f_{c m}$. When detailed laboratory results are not available, it is still possible to plot the concrete

383 stress-strain curve using an appropriate formula. In this study the concrete stress-strain

384 relation adopted is the one given by equation 3.14 from the BS EN 1992-1-1 (BSI, 2004). A

385 weakening non-linear curve for the tension stiffening, shown in Figure 12, was used in the

386 model validation (Wang and Hsu, 2001). The relation is given in Equation 22. The suggested

387 value for $\varepsilon^{\star}$, corresponding to a zero value of the stress, can be assumed equal to ten times the

388 strain at which $f_{c t m}$ is reached (Simulia, 2012). A value of 0.01 is recommended.

389

$$
\left\{\begin{array}{c}
\sigma_{t}=E_{c} \varepsilon_{t} \quad \text { if } \quad \varepsilon_{t} \leq \varepsilon_{c r} \\
\sigma_{t}=\left(\frac{\varepsilon_{c r}}{\varepsilon_{t}}\right)^{0.4} \text { if } \varepsilon_{t}>\varepsilon_{c r}
\end{array}\right.
$$

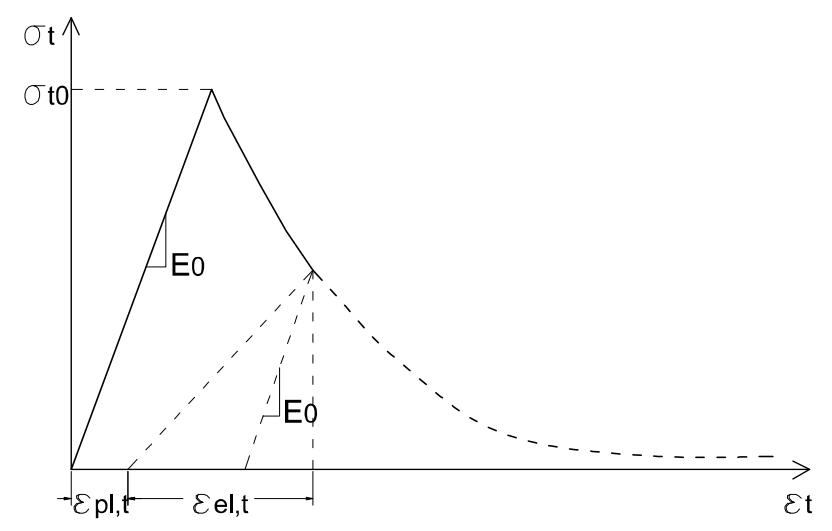

390

391

392

393

394

Figure 12. Modelling of RC structures and composite structures with concrete strength degradation taken into consideration

\section{Table 16. Concrete damaged plasticity parameters}

\begin{tabular}{|l|l|l|l|l|}
\hline $\begin{array}{l}\text { Dilation } \\
\text { angle }\end{array}$ & Eccentricity & $\mathrm{fb}_{\mathrm{b} 0} / \mathrm{f}_{\mathrm{c} 0}$ & $\mathrm{~K}_{\mathrm{C}}$ & $\mu$ \\
\hline 36 & 0.1 & 1.16 & $\begin{array}{l}0.66 \\
7\end{array}$ & 0 \\
\hline
\end{tabular}


400 The properties of the steel reinforcement used in the models were gathered from associated 401 experimental data. An elastic perfectly plastic stress-strain curve was used. The steel material properties were defined using isotropic linear elasticity up to the yield stress $\sigma_{y}$, using the Young's modulus, E, and the Poisson's ratio, v.

\subsection{FRP}

405 Two major aspects of FRP that are important to consider when modelling the material are: its 406 linear behaviour up to failure and that the physical properties are directionally dependent. $\square$ The 407 rebar behaviour can be defined as perfectly elastic up to the ultimate stress of the material. By 408 modelling the rebar using wire truss elements it is not necessary to define properties in multiple directions, this is deemed to be a reasonable approximation.

\subsection{Elements}

411 Two types of elements were used in this paper: two-node elements to model the reinforcement 412 and eight-node linear brick elements to model the concrete. The interaction between the two 413 materials was considered a perfect bond; as previously mentioned, this is a main factor of 414 uncertainty, considering how much the bond between the concrete and the FRP rebar can 415 influence the behaviour of the element (Achillides and Pilakoutas, 2004; Lin and Zhang, 2014).

\section{4. Design Series FE Models}

\section{$417 \quad$ 4.1. Geometry and material properties}

418 The slabs designed in Section 2.6 were then analysed using non-linear FE. The slabs' material 419 properties can be found in Tables 17-19. To reduce the computational time, the symmetry of the slabs was considered. The portion of the slabs modelled in Abaqus is shown in Figures 13,

42116 and 18. The loads were applied in increments until failure occurred, in some cases several times the load dictated by the ultimate limit state design case. Mesh sensitivity studies were undertaken together with the model validation to define the optimum mesh density for the different models; other sensitivity tests included the viscosity and tension stiffening parameters

425 (Stuart, 2014). Eight-node linear brick elements with a thickness of $30 \mathrm{~mm}$ were used to model 426 the slabs, based on the results from the validation study (Stuart, 2014). Solid-extrude and Wire 427 features were used in Abaqus to model the slabs and the reinforcement, respectively. For the one-way simply supported slab a regular mesh with $200 \mathrm{~mm}$ square elements was adopted 
(Figures 14 and 15). Similarly, for the two-way spanning slab, square elements with edges not greater than $200 \mathrm{~mm}$ were used. However, the density of the mesh was adapted to have a higher number of elements close to the edges and larger elements in areas with smaller stress gradient, as shown on Figure 17. The sizes of the elements ranged from 40 to $200 \mathrm{~mm}$. In the flat slab model a mesh similar to the one adopted for the two-way spanning slab was used (Figure 19). The column supporting the slab was considered to be $1.5 \mathrm{~m}$ long on both sides of the slab, tied to its surface and fully fixed at the edges (Figure 20). Common steel was used as longitudinal and transversal reinforcement in the column, with a C30/37 concrete. Regarding the conventions used to present the results, the unit kNm is used for bending moment, MPa when describing stresses and $\mathrm{mm}$ for deflections. Black dashed lines are used to identify axes of symmetry.

Table 17. Boundary conditions

\begin{tabular}{|l|l|l|l|l|l|}
\hline \multirow{2}{*}{$\begin{array}{l}\text { One-way GF } \\
\text { RC slab }\end{array}$} & Ulement & U2 & UR2 & UR3 \\
\cline { 2 - 7 } & Vertical mid-span face & 0 & free & 0 & 0 \\
\cline { 2 - 6 } & Support & free & 0 & free & free \\
\hline
\end{tabular}

(1) x-axis: longitudinal axis, (2) y-axis: vertical axis, (3) z-axis: transverse axis.

\begin{tabular}{|l|l|l|l|l|l|l|l|}
\hline $\begin{array}{l}\text { Two- } \\
\text { way } \\
\text { GFRP } \\
\text { RC slab }\end{array}$ & Face & U1 & U2 & U3 & UR1 & UR2 & UR3 \\
\cline { 2 - 8 } & AD & free & 0 & free & 0 & 0 & free \\
\cline { 2 - 8 } & $\mathrm{CD}$ & free & free & 0 & 0 & 0 & free \\
\cline { 2 - 8 } & $\mathrm{BC}$ & 0 & free & free & free & 0 & 0 \\
\hline \multirow{4}{*}{$\begin{array}{l}\text { GFRP } \\
\text { RC flat } \\
\text { slab }\end{array}$} & Face & U1 & U2 & U3 & UR1 & UR2 & UR3 \\
\cline { 2 - 8 } & AB & free & free & free & free & free & free \\
\cline { 2 - 8 } & $\mathrm{AD}$ & free & free & free & free & free & free \\
\cline { 2 - 8 } & $\mathrm{BC}$ & 0 & free & free & free & 0 & 0 \\
\cline { 2 - 8 } & $\mathrm{CD}$ & free & free & 0 & 0 & 0 & free \\
\hline
\end{tabular}

\begin{tabular}{|l|l|l|l|l|l|l|l|}
\hline GFRP & Face & U1 & U2 & U3 & UR1 & UR2 & UR3 \\
\hline
\end{tabular}




\begin{tabular}{|l|l|l|l|l|l|l|l|}
\hline \multirow{4}{*}{$\begin{array}{l}\text { RC } \\
\text { flat } \\
\text { slab }\end{array}$} & AB & free & free & free & free & free & free \\
\cline { 2 - 8 } & AD & free & free & free & free & free & free \\
\cline { 2 - 8 } & BC & 0 & free & free & free & 0 & 0 \\
\cline { 2 - 8 } & CD & free & free & 0 & 0 & 0 & free \\
\hline
\end{tabular}

(1) x-axis: parallel to $\mathrm{AB},(2) \mathrm{y}$-axis: vertical axis, (3) z-axis: parallel to AD.

444 Table 18. Concrete properties

445

\begin{tabular}{|ll|l|l|l|l|}
\hline & $\begin{array}{l}\mathrm{f}_{\mathrm{c}}^{\prime} \\
(\mathrm{MPa})\end{array}$ & $\begin{array}{l}\mathrm{f}_{\mathrm{cm}} \\
(\mathrm{MPa})\end{array}$ & $\begin{array}{l}\mathrm{E}_{\mathrm{c}} \\
(\mathrm{MPa})\end{array}$ & $v$ \\
\hline $\begin{array}{l}\text { One-way } \\
\text { slab }\end{array}$ & 35 & 43 & 34007 & 0.2 \\
\hline $\begin{array}{l}\text { Two-way } \\
\text { slab }\end{array}$ & 30 & 38 & 32827 & 0.2 \\
\hline RC flat slab & 20 & 28 & 28042 & 0.2 \\
\hline
\end{tabular}

446 Table 19. GFRP rebar properties

447

448

449

450

451

452

453

454

455

\begin{tabular}{|l|l|l|l|l|l|l|}
\hline & $\begin{array}{l}\text { Diameter } \\
(\mathrm{mm})\end{array}$ & Area & $\begin{array}{l}\text { fu } \\
\left(\mathrm{mm}^{2}\right)\end{array}$ & $\begin{array}{l}\text { Es } \\
(\mathrm{MPa})\end{array}$ & $\varepsilon_{0}$ & $v$ \\
\hline $\begin{array}{l}\text { One-way } \\
\text { slab }\end{array}$ & $\begin{array}{l}9.9 \\
11.90\end{array}$ & 71 & 775 & 45000 & 0.017 & 0.3 \\
& 23.40 & 434 & 775 & 45000 & 0.017 & 0.3 \\
\hline $\begin{array}{l}\text { Two-way } \\
\text { slab }\end{array}$ & 19.5 & 298 & 775 & 45000 & 0.017 & 0.3 \\
\hline RC flat slab & 19.5 & 298 & 775 & 45000 & 0.017 & 0.3 \\
& 19.9 & 251 & 775 & 45000 & 0.017 & 0.3 \\
\hline
\end{tabular}

\subsection{Results}

The three models show a brittle failure due to concrete crushing, as predicted by the codes. The shape of the load- displacement curves matches the expectations and the results of the validation models, meaning that the behaviour of the slab was simulated correctly. The loaddisplacement curves can be divided into two parts

- A first segment where the concrete is carrying most of the load and the slope of the curve is governed by the elastic modulus of the concrete 
- A second linear segment that follows the cracking of the concrete and in which the FRP rebar starts to carry an increasing portion of load up to the failure due to concrete crushing.

The results from the analysis in Abaqus are presented next. Reference is made to SLS and ULS as the stages where the factored design load at serviceability limit state and at ultimate limit state, respectively, were applied. The third and final stage presented, referred to as failure, is the stage where the maximum strength of the material is reached under the load applied.

\subsubsection{One-way GFRP RC slab}

Results from the ABAQUS model presenting the principal stress distribution at different load stages are shown in Figures 21 and 22. When the maximum strength of concrete is reached, the FE analysis continues to redistribute stresses to adjacent material up to a point where there is no more residual strength to be used. In reality, failure occurs when the maximum strength of one of the two materials is reached, in this particular case the strength of the concrete. Localised crushing of concrete first occurred at around $37 \mathrm{kN} / \mathrm{m}^{2}$ in the mid-span; the magnitude of the loads at SLS and ULS is high- lighted in Figure 23. Subsequent to the onset of concrete crushing and given the low stress in the rebar, further loading of the slab was achieved. At these later stages, membrane action is engaged with eventual rebar rupture occurring at around 90 $\mathrm{kN} / \mathrm{m}^{2}$. Such an enhancement in ultimate strength over the service loads as a result of membrane action is consistent with that observed in tests of traditional steel reinforced slabs (e.g. Gouverneur et al., 2013).

In Figure 23 and other similar load-deflection curves, the deflections/stress under SLS and ULS loads are identified with a triangle and a square, respectively, while the circle represents the first onset of concrete crushing. The bending moment corresponding to the onset of concrete crushing (and similar) was identified as the moment resistance of the slab and compared to the moment resistance calculated using the codes (which is considerably higher than the bending moment under the ULS load). As shown in Figure 24, the stress in the FRP reinforcement is well within the material strength at the first onset of concrete failure. 


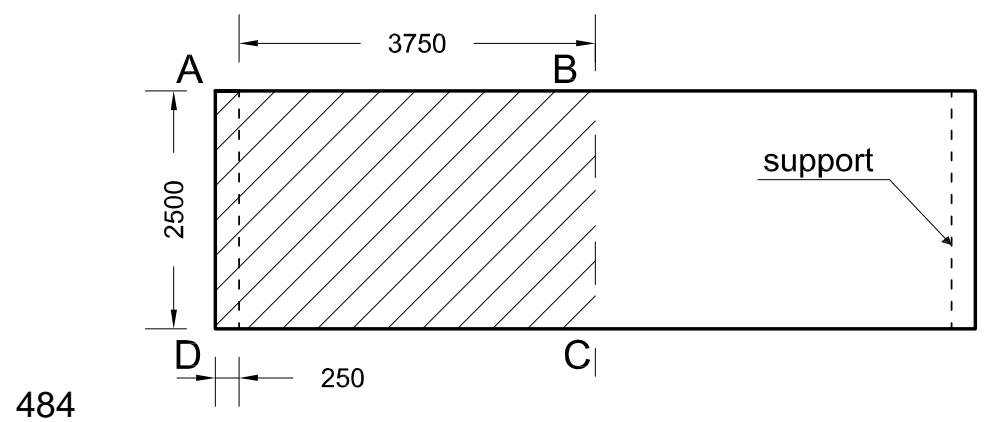

485 Figure 13. One-way GFRP RC slab - FE model geometry (dimensions: mm). Hatched area 486 represents the portion of the slab modelled in Abaqus

487

488

489

490

491

492

493

494

495

496

497

498

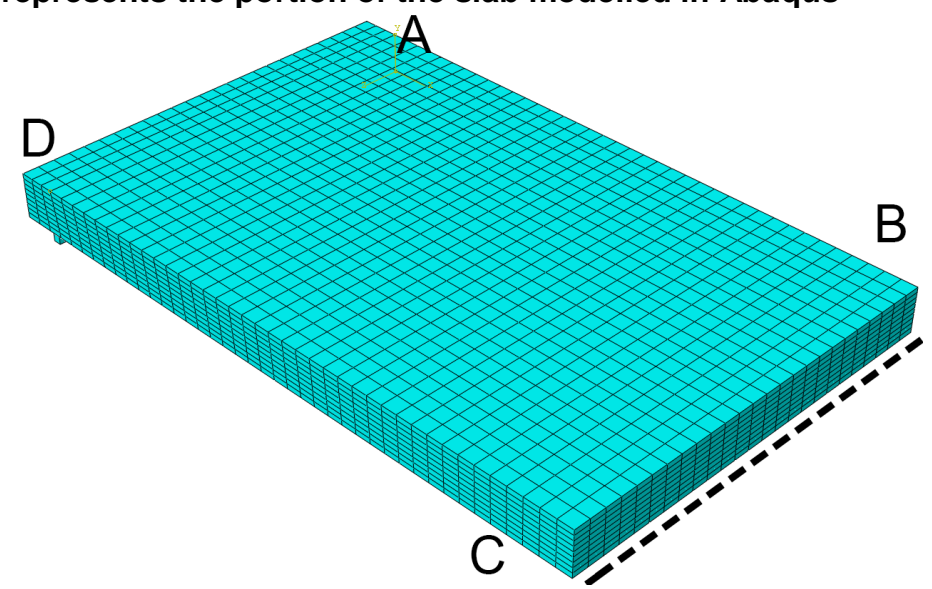

Figure 14. One-way GFRP RC slab model - mesh

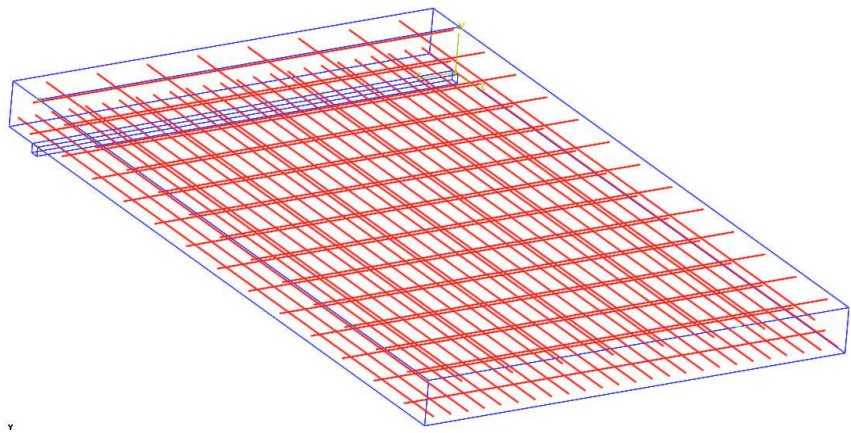

Figure 15. One-way GFRP RC slab - FE model geometry, slab outline and reinforcement distribution

\subsubsection{Two-way GFRP RC slab}

The load displacement curve for the two-way slab is provided in Figure 27, together with the SLS and ULS loads. As in the one-way slab, the onset of concrete crushing occurs long before rupture of the FRP. The distribution of the principal stresses in the slab at failure and ULS, is shown in Figures 25 and 26, respectively. The load displacement curve for the two-way slab is provided in Figure 27, together with the SLS and ULS loads. The load levels at which those 
500 of the slab are far in excess of practical limits. Again, this behaviour is made possible by the 501 generation of membrane action in the slab.

502

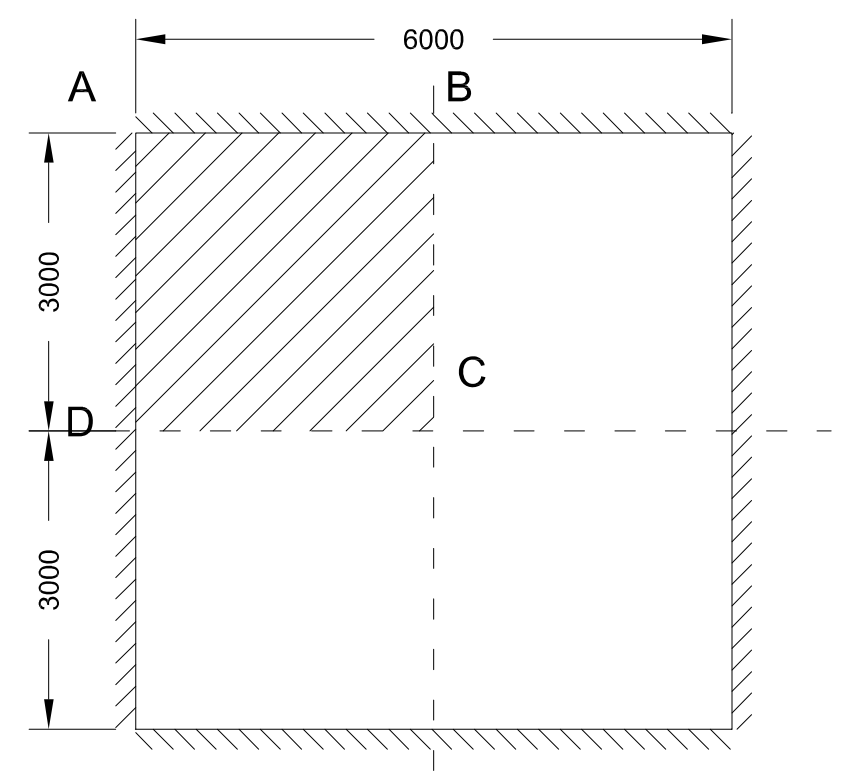

Figure 16. Two-way GFRP RC slab - FE model geometry (dimensions: $\mathrm{mm}$ ). Hatched area represents the portion of the slab modelled in Abaqus

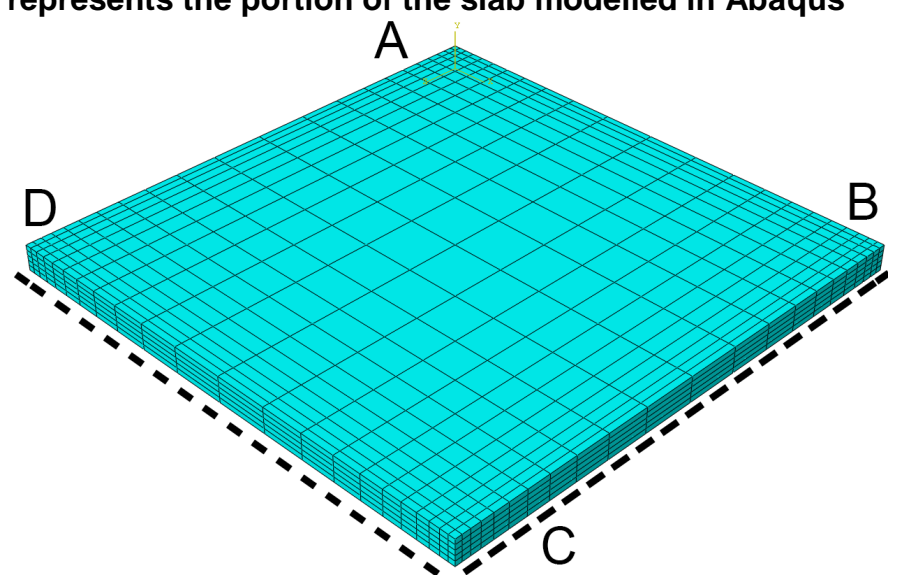

505

Figure 17. Two-way GFRP RC slab model - mesh

507

508

\subsubsection{GFRP RC Flat slab}

509 The stress distribution in the slab at ULS and SLS is presented in Figures 29 and 30,

510 respectively, with the points corresponding to relevant load stages identified in Figures 31 and

511 32. As the slab is considerably over-reinforced, the model is able to redistribute the load multiple

512 times, reaching a load-carrying capacity much higher than the ULS design load. As for the

513 previous cases, the onset of concrete crushing occurred while the FRP rebar was still relatively 
514 lightly stressed. Extensive residual capacity of the rebar mesh allowed further load-carrying

515 capacity to be achieved, with eventual rebar rupture occurring around $88 \mathrm{kN} / \mathrm{m}^{2}$.

516

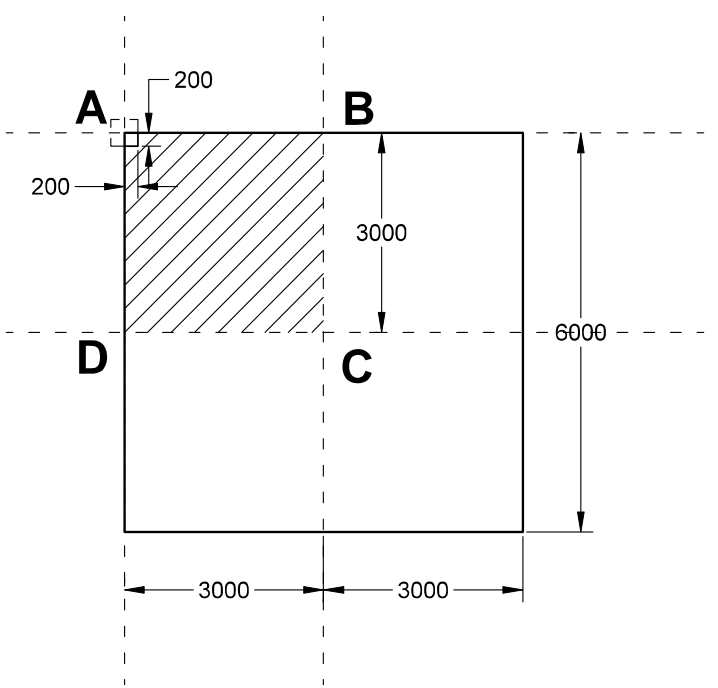

517 Figure 18. GFRP RC flat slab: one-quarter of the structure - FE model geometry

518 (dimensions: $\mathrm{mm}$ ). Hatched area represents the portion of the slab modelled in Abaqus

519

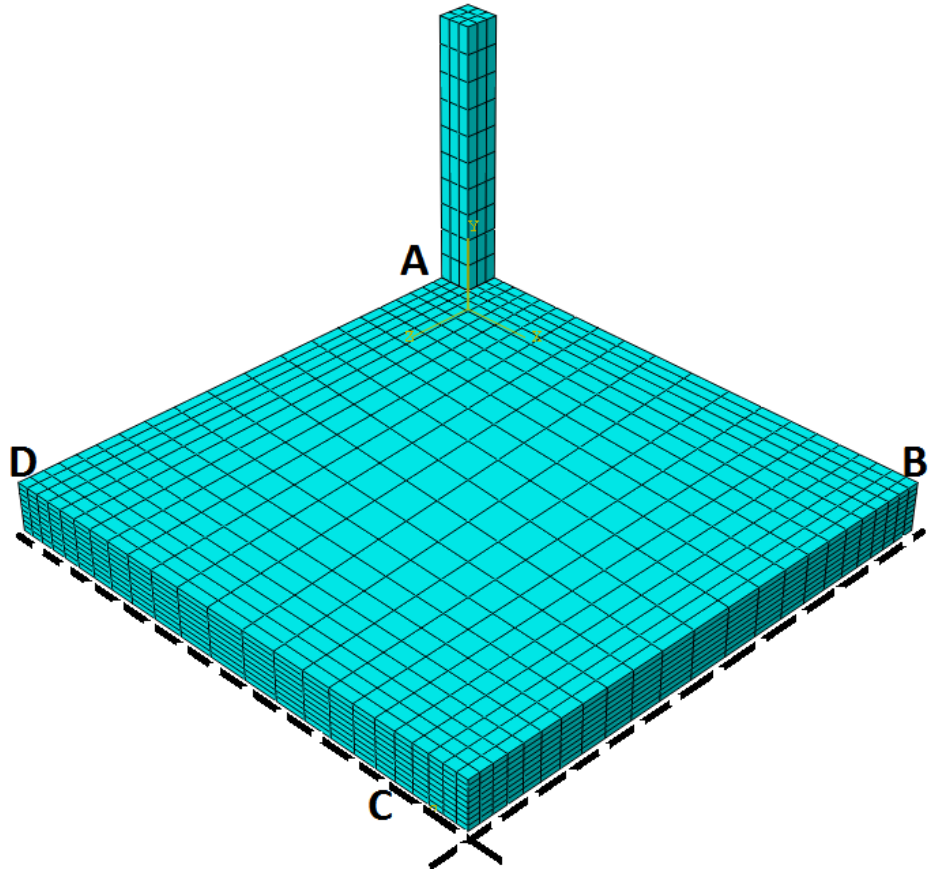

520 Figure 19. Flat GFRP RC slab model - mesh 


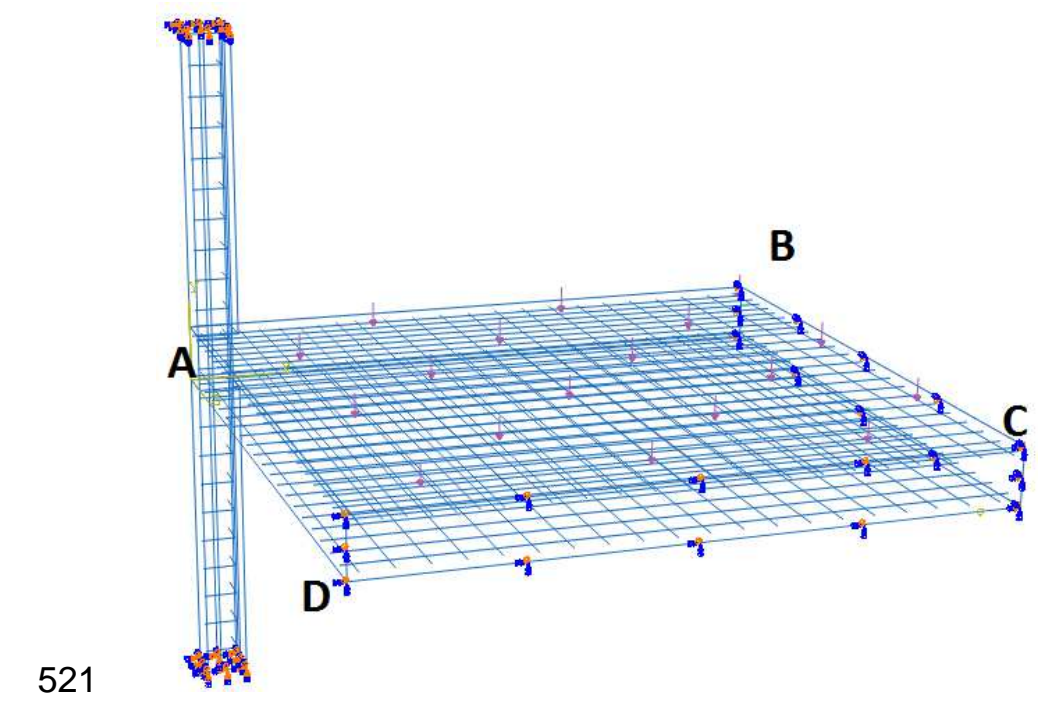

522 Figure 20. GFRP RC flat slab: boundary conditions

523

524

4.3. Comparison with the Code predictions

525 The results obtained are collated and presented in Figure 33, with the results from the FE analysis overlain in light grey. If looking at the results given by the modified Eurocode approach

527 (denoted EN on the diagram), for the bending moment resistance, the one-way slab has a resistance of $302 \mathrm{kNm}$, while the slab fails under an applied bending moment of $256 \mathrm{kNm}$ according to the FE model, taking onset of concrete crushing as the failure load. Considering the stress in the rebar at ULS, the modified Eurocode approach gives a value of $321 \mathrm{MPa}$, 531 against the $263 \mathrm{MPa}$ from the FE analysis. Finally at SLS, the Abaqus model gives a rebar 532 stress of $6.5 \mathrm{MPa}$, against the $79 \mathrm{MPa}$ given by the modified Eurocode design. If looking at the 533 bending moment resistance of the slabs, it is possible to state that the modified European 534 approach (Eurocode) gives potentially non-conservative results for the one-way slab and the flat 535 slab, while the prediction for the two-way slab is fairly accurate. The ACI and CSA give an 536 accurate result for the one-way slab and two-way slab, and potentially non-conservative results 537 for the flat slab. At ULS the code predictions of the stress in the rebar maintains a certain ratio in 538 the different models, the prediction is quite accurate and conservative. The modified Eurocode approach gives lower values for the stress for all the three models. The CSA gives higher

540 values than the other codes, for the one-way slab the stress at ULS is double the stress 541 recorded in the FE model. The stress in the rebar at failure is always below the maximum 542 strength, meaning that the equations proposed to estimate the balanced failure ratio are 
543 reliable. Considering that the SLS governs the design of the three slabs, the amount of 544 reinforcement and the depth of the cross-sections had to be increased considerably, in 545 comparison to the requirements from the ULS. However, the resulting bending moment capacity 546 is still lower or not sufficiently higher than the FE model prediction in some cases. The checks 547 for the SLS give conservative results, which is a priority when designing a structure. However,

548 the codes provide overly conservative results, overestimating the stress more than ten times. It 549 is important to remember that the results are being compared with the FE models, and this 550 discrepancy could be attributed in part to inaccuracy of the numerical strain in the rebar in the 551 pre- cracking phase, as outlined in Section 3.1. When comparing the code prediction with the 552 earlier mentioned experimental tests of Benmokrane et al. (2004), as shown in Figure 34, the 553 code prediction for the stress at SLS is much closer to the experimental results. A possible 554 reason for the underestimation of the stresses in the FE models may be the CDP model, over555 estimating the resistance of the concrete for low levels of load, in particular the tensile strength 556 (which in practice can be variable), in combination with uncertainties over rebar bond. 557 Observation of the experimental results reveals the same general pattern between code 558 predictions as the designed one- way slab. Both the $7.5 \mathrm{~m}$ case study slab and the Benmokrane 559 slab have very similar reinforcement ratios, while the span-to- depth ratios are $27 \cdot 3$ and $16 \cdot 7$, 560 respectively. It should be noted that, in the Benmokrane test, the moment on first cracking in the 561 experiment was $13 \mathrm{kNm}$; at the SLS design load the corresponding moment is just beyond this 562 at $14.5 \mathrm{kNm}$. This is in contrast to the $7.5 \mathrm{~m}$ case study slab, where the SLS design moment 563 exceeds the theoretical moment on first cracking by almost $100 \%$. Further investigation is 564 needed to find out if this early behaviour is also noticed in other similar applications.
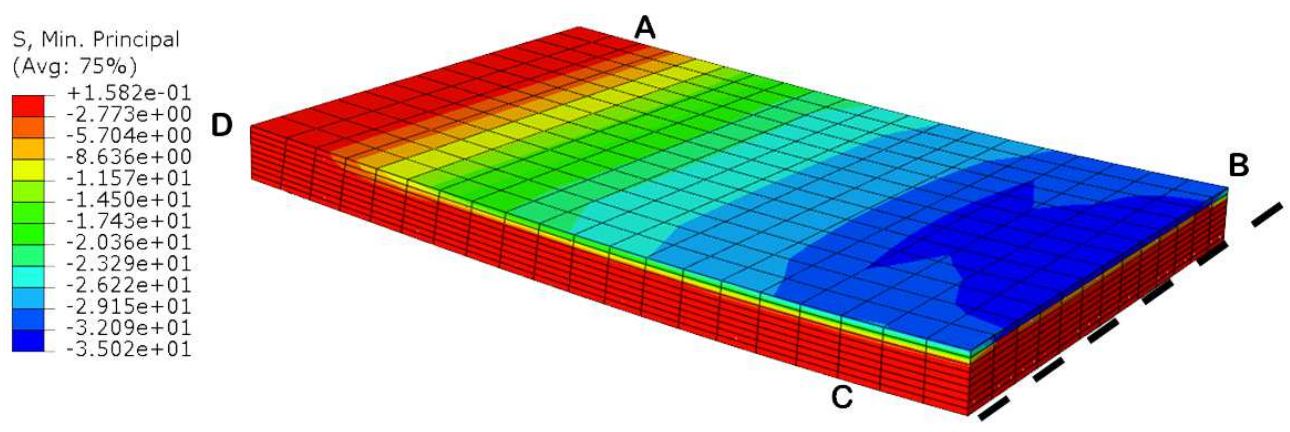

Figure 21. One-way GFRP RC slab: min. principal stresses in concrete at failure (MPa) 
S, Max. Principal

S, Mid. Principal

S, Min. Principal

$+3.574 \mathrm{e}+00$
$+2.415 \mathrm{e}+00$

$+1.256 \mathrm{e}+00$

$1063 e+00$

$-2.222 \mathrm{e}+00$

$-4.341 e+00$

5.699 (1)



$-1.033 e+01$

A IB

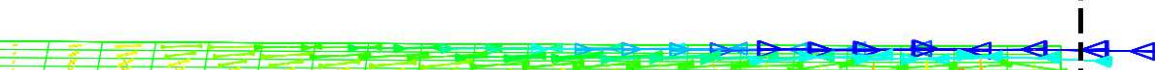

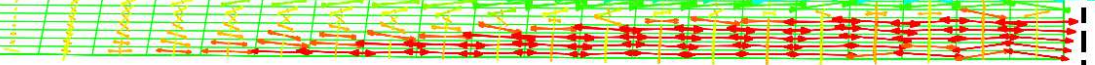

(a)

$+3.547 e+00$ $+3.124 \mathrm{e}-01$ $-6.157 \mathrm{e}+00$ $-9.392 \mathrm{e}+00$ $-1.263 \mathrm{e}+0.1$ $1.9100+01$ .

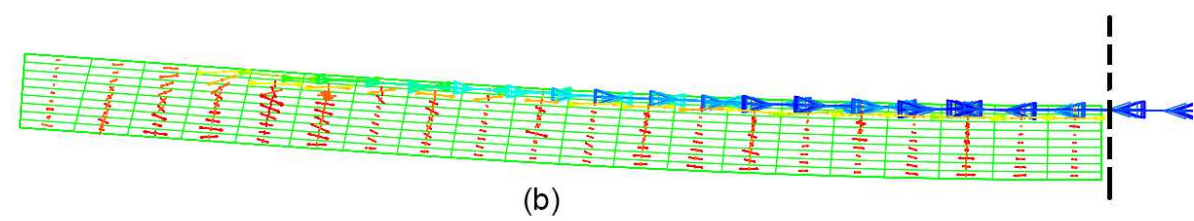

Figure 22. One-way GFRP RC slab: max./min. principal stresses in concrete (a) at ULS and $(\mathrm{b})$ at failure (MPa)

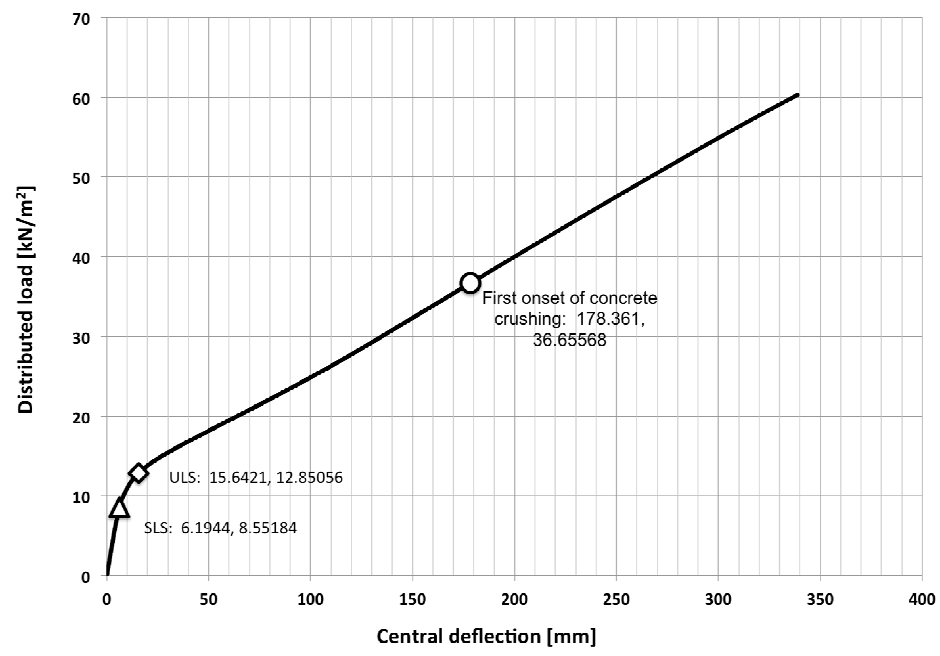

571 Figure 23. One-way GFRP RC slab: Abaqus load-displacement curve



Figure 24. One-way GFRP RC slab: stress in bottom longitudinal reinforcement, at midspan 
575
576 577

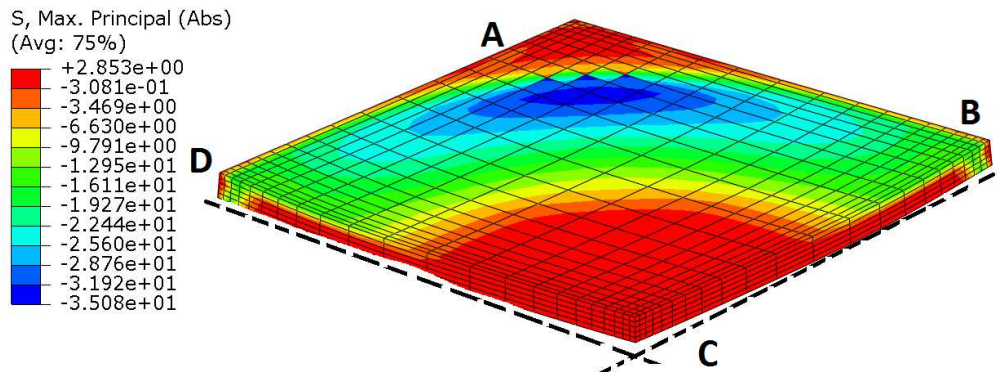

Figure 25. Two-way GFRP RC slab: max. principal stresses in concrete at failure (MPa)

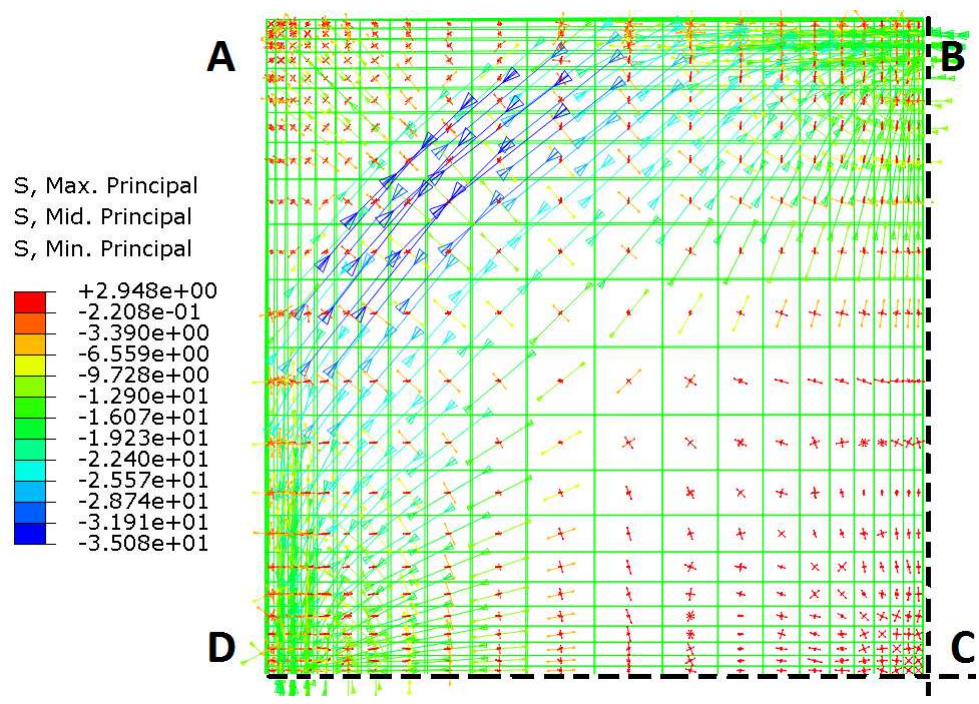

Figure 26. Two-way GFRP RC slab: max./min. principal stresses in concrete at ULS (MPa) (both stresses at the top and bottom surfaces of the slab are shown)

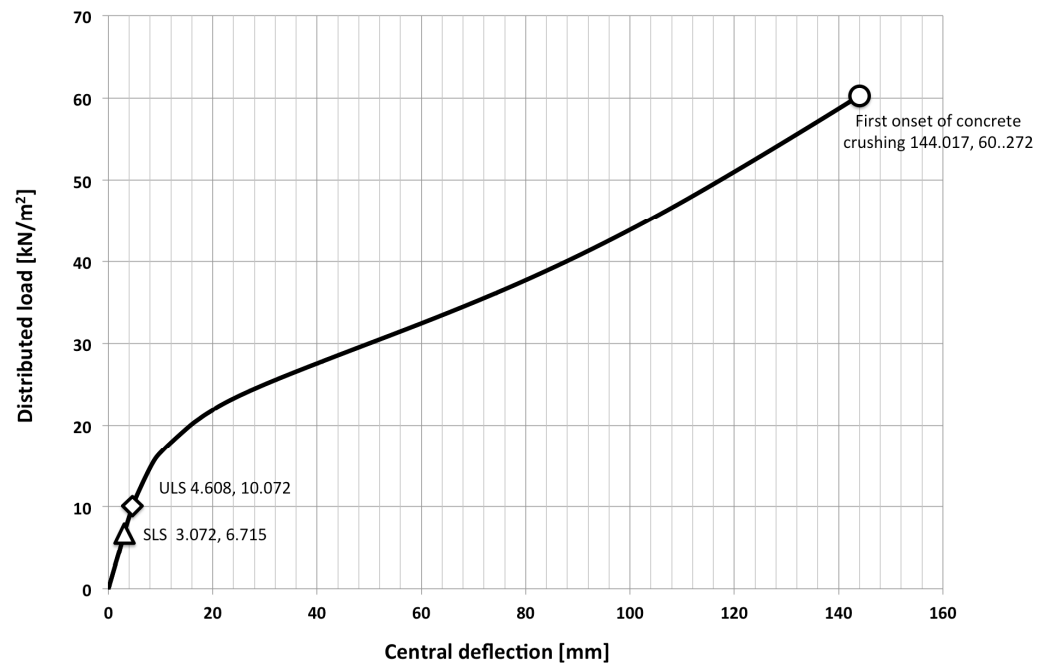

Figure 27. Two-way GFRP RC slab: Abaqus load-displacement curve 


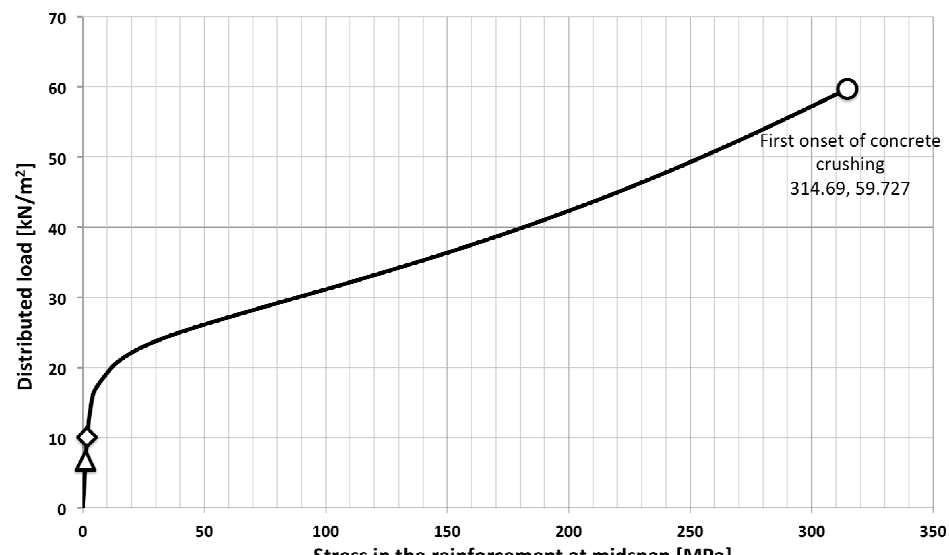

Stress in the reinforcement at midspan [MPa]

Figure 28. Two-way GFRP RC slab: stress in the bottom reinforcement, at mid-span

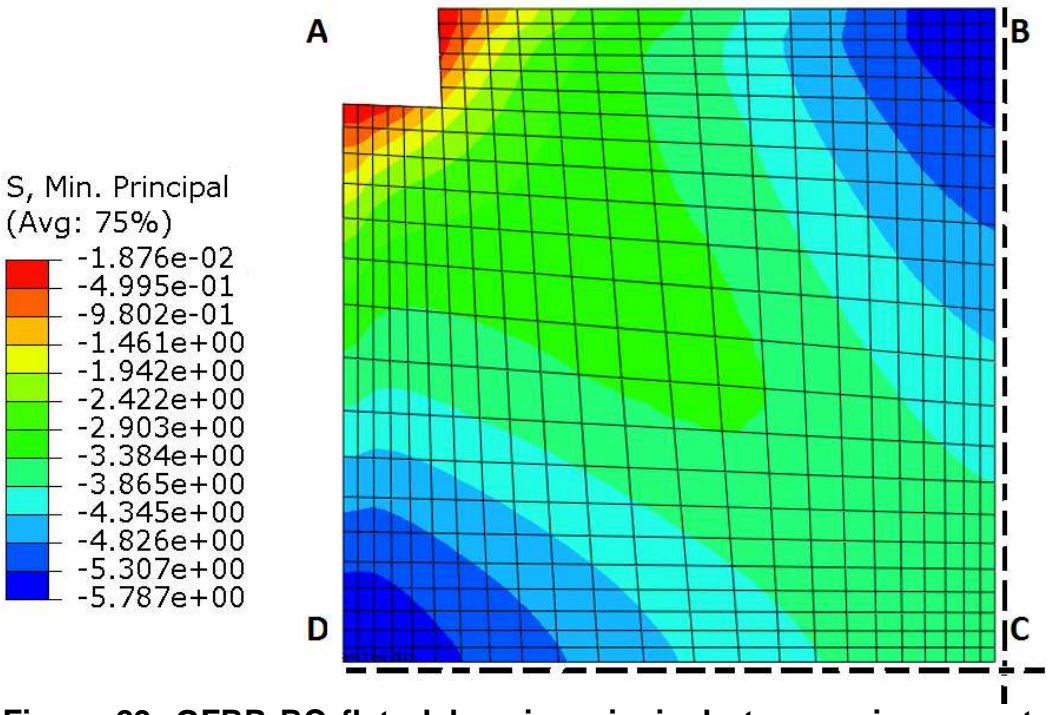

Figure 29. GFRP RC flat slab: min. principal stresses in concrete at ULS (MPa) - plan 591 view

S, Max. Principa

S, Mid. Principal

$S$, Min. Principal

$+2.658 \mathrm{e}+00$

$+1.987 \mathrm{e}+00$

$+1.315 \mathrm{e}+00$

$+6.437 \mathrm{e}-01$

$-6.783 \mathrm{e}-02$

$-6.993 \mathrm{e}-01$

$-2.042 e+00$

$-2.714 \mathrm{e}+00$

$-3.385 \mathrm{e}+00$

$-4.057 \mathrm{e}+00$

$-4.728 \mathrm{e}+00$

$-5.400 \mathrm{e}+00$

A

D

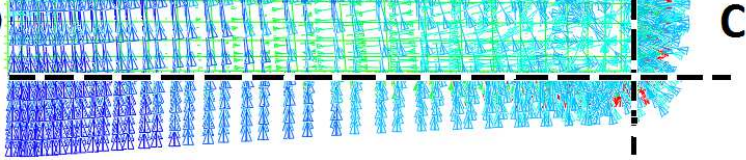

c

B 
Figure 30. GFRP RC flat slab: vector plot of max./min. principal stresses in concrete, at SLS (MPa) - plan view. The column was removed from the view for clarity

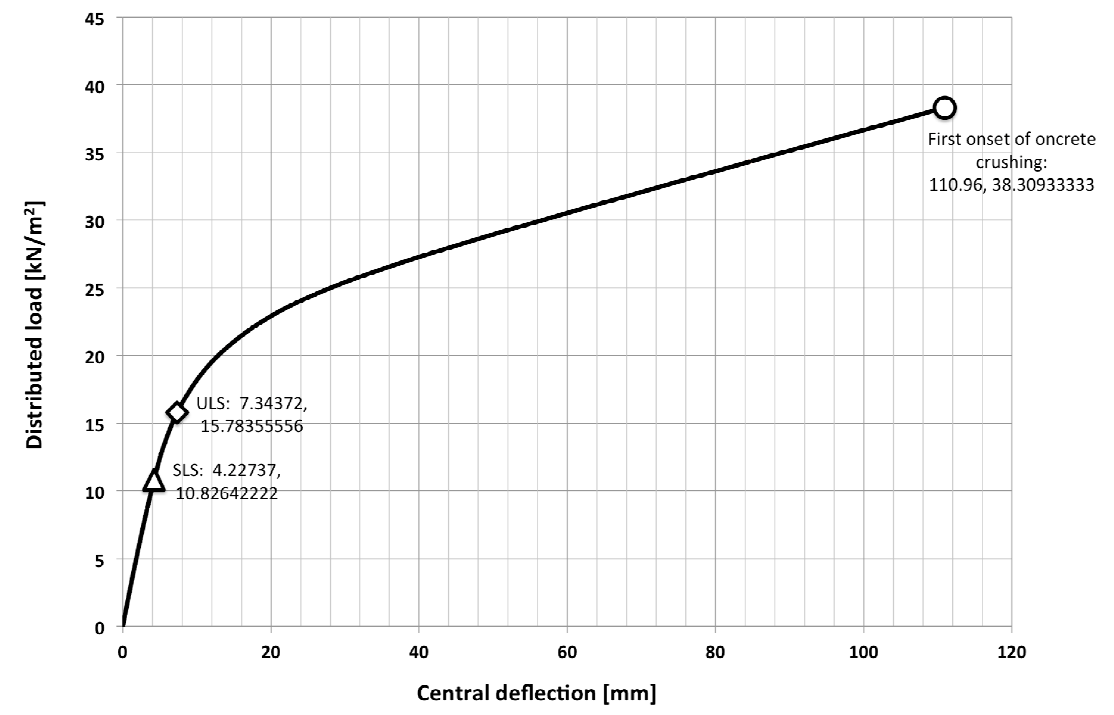

Figure 31. GFRP RC flat slab: Abaqus load-displacement curve at point C

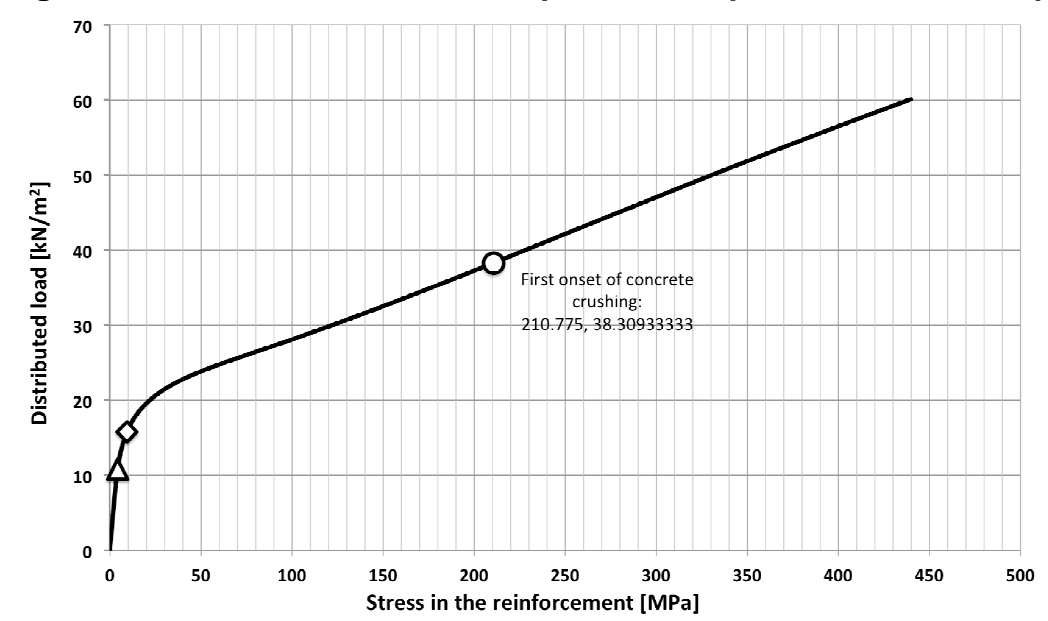

\section{Figure 32. GFRP RC flat slab: stress in the bottom reinforcement at point B}

599

600

\section{Conclusions}

601 This paper has presented a comparative review of design approaches to FRP bars as a reinforcement for concrete members, with an introduction to the materials and their properties,

603 the behaviour of the composite and the available inter- national codes. In order to make the FRP reinforcement a strong alternative to traditional reinforcement, the performance prediction from the codes has to be as accurate as possible considering that rough approximations in the design imply a significant increment of the costs. Considering the existing design codes, a

607 possible design path was proposed in Section 2, gathering the recommendations from

608 Pilakoutas et al. (2011), fib and CNR. Following this approach, in addition to the ACl code and 
609 the CSA standard recommendations, it was shown how the design of FRP RC elements is 610 governed by the SLS requirements. Also, when designing for a ductile failure the amount of 611 FRP rebar required is elevated. As a consequence, designing the element to be over-reinforced 612 requires an amount of rebar that causes the element price to be uncompetitive in comparison 613 with a similar steel RC element and potentially for some stainless steel grades. The 614 reinforcement required to guarantee concrete crushing can be reduced by reducing the thick615 ness of the slab; however, the design at SLS sets a lower boundary to the minimum amount of 616 concrete necessary in order to avoid excessive deflection and cracking. To achieve an efficient 617 design, an accurate prediction of the stress in the concrete at SLS is necessary. More research 618 is needed in this regard. This study has focused on flexure; however, some elements and 619 particularly flat slabs may be vulnerable to shear. The designs presented in this paper were 620 chosen such that flexural failure governs. The results of the CDP model validation show how 621 Abaqus is able to correctly describe the load-deflection curve and mode of failure of the 622 concrete elements. For the purpose of the FE model, the bond between the reinforcement and 623 the concrete was assumed as perfect. However, as emerged from the first part of the study, this 624 assumption does not accurately represent the real interaction between the two components. 625 This can significantly influence the performance of the structural element in the pre-cracking 626 phase. Further research and adoption of appropriate bond-slip models is needed in order to 627 improve the accuracy of future FE models. The codes predictions were compared with the FE 628 analysis results, showing that, for the case of the one-way slab and flat slab, the designs are 629 potentially non-conservative with respect to flexure. Furthermore, a discrepancy between the 630 codes' prediction at SLS and the FEA results was shown. The evidence from this study 631 suggests that the Canadian approach emerges as the most conservative one, while the 632 modified Eurocode approach gives quite accurate, but still potentially non-conservative 633 predictions for the stress at ULS in the rebar. Finally, the findings of this study have raised some 634 doubts regarding the results given by the codes for different GFRP RC slabs. However, the 635 general implication of the results is limited by the small sample size and further research is 636 needed in order to study the response of a greater set of specimens, combining both 637 experimental and analytical work. Further research is needed to investigate the performance of 638 FRP RC elements under fire. Owing to the nature of the material, a substantial amount of 
reinforcement is needed to guarantee the safety of the structure under fire. This leads to bigger

640 and heavier elements, which are uneconomical both because of the increased dead load and

641 because of the amount of reinforcement required to assure a ductile failure of the element. It is

642 recommended that further research be under- taken to define a possible solution for decreasing

643 the concrete area without a substantial reduction of the moment of inertia of the cross-section. A

644 possible approach for this issue could be the combination of hollow-core slabs and FRP

645 reinforcement. As the SLS design case is critical for the design of FRP RC elements, further

646 investigation is needed to refine the prediction of the codes especially considering the difference

647 with the numerical models results. Finally, an internationally recognised manufacturing standard

648 for the FRP rebar would make use of this material easier for designers, and contribute to the

649 more widespread use of this technique.

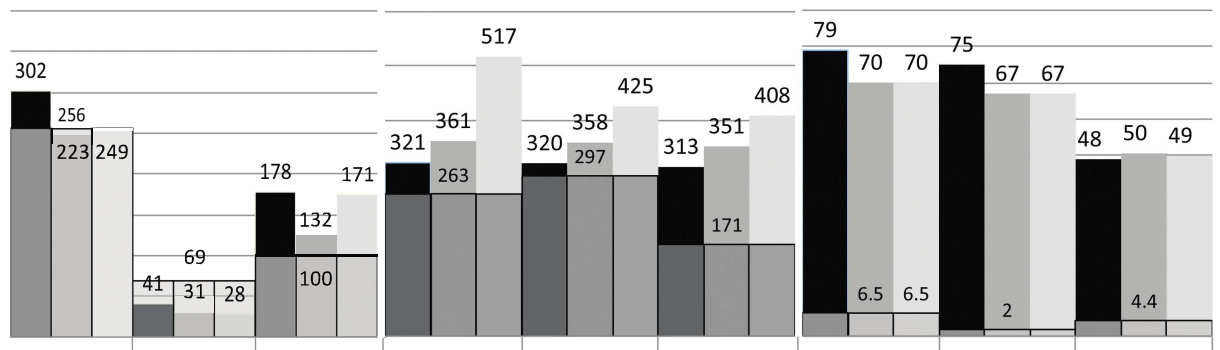

EN ACI CSA EN ACl CSA EN ACI CSA EN ACI CSA EN ACI CSA EN ACI CSA EN ACl CSA EN ACl CSA EN ACI CSA

\begin{tabular}{|c|c|c|c|c|}
\hline $\begin{array}{c}\text { One way slab Two way slab } \\
\text { Mrd }\end{array}$ & Flat slab & $\begin{array}{r}\text { One way slab Two way slab } \\
\text { Stress at ULS [MPa }\end{array}$ & Flat slab & $\begin{array}{c}\text { One way slab Two way slab Flat slab } \\
\text { Stress at SLS [MPa] }\end{array}$ \\
\hline
\end{tabular}

Figure 33. Code comparison: bending moment resistance at mid-span (kNm); stress in the rebar at ULS (MPa) - GFRP bar at mid-span (one- and two-way slabs) and at the column strip for the flat slab; stress in the rebar at SLS (MPa) - GFRP bar at mid-span (one- and two-way slabs) and at the column strip for the flat slab

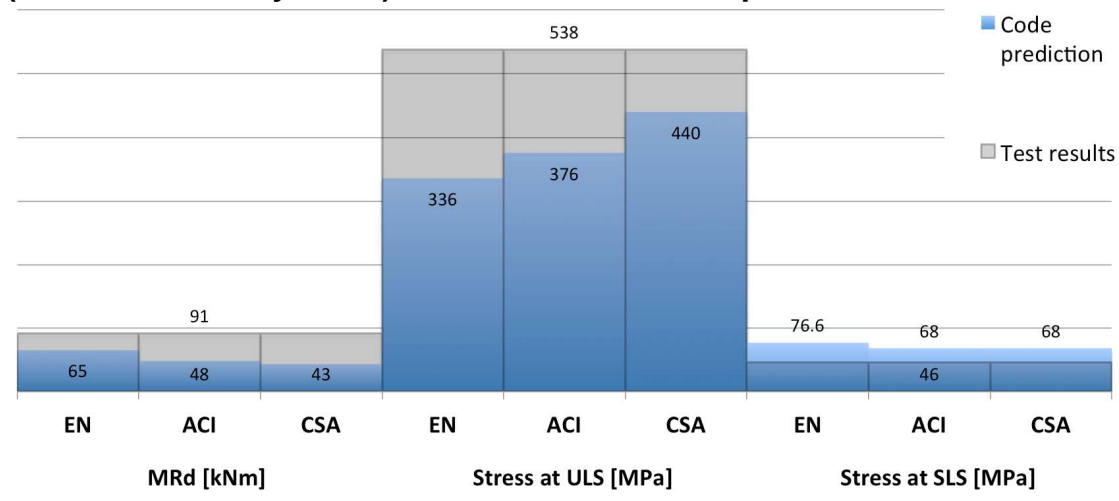

One Way Slab et al., 2004) - bending moment resistance at mid-span $(\mathrm{kNm})$ (failure due to concrete crushing). Stress in the rebar at ULS (MPa) - GFRP bar at mid-span. Stress in the rebar at SLS (MPa) - GFRP bar at mid-span 
References

Achillides Z and Pilakoutas K (2004) Bond behavior of fiber reinforced polymer bars under direct pullout conditions. Journal of Composites for Construction 8(2): 173-181.

664

ACI (American Concrete Institute) (2003) ACI 440.1R-03: Guide for the design and 666 construction of concrete reinforced with FRP bars. American Concrete Institute, Farmington Hills, MI, USA.

668

$\mathrm{ACl}$ (2006) ACI 440.1R-06: Guide for the design and construction of structural concrete reinforced with FRP bars. American Concrete Institute, Farmington Hills, MI, USA.

671

672

$\mathrm{ACl}$ (2015) ACI 440.1R-15: Guide for the design and construction of structural concrete reinforced with fiber-reinforced polymer (FRP) bars. American Concrete Institute, 674 Farmington Hills, MI, USA.

675

Balafas I and Burgoyne CJ (2012) Economic design of beams with FRP rebar or prestress. Magazine of Concrete Research 64(10): 885-898.

678

679 Benmokrane B, El-Salakawy E, Cherrak Z and Wiseman A (2004) FRP composite bars for 680 the structural concrete slabs of a public works and government service Canada parking 681 garage. Canadian Journal of Civil Engineering 31(5): 730-746.

682

683

Branson D (1968) Design procedures for computing deflections.

684 ACI Structural Journal 65(8): 730-742.

685

686 BSI (2002) BS EN 1990:2002+A1:2005: Eurocode: Basis of structural

687 design. BSI, London, UK.

688

BSI (2004) BS EN 1992-1-1:2004: Eurocode 2: Design of concrete 
structures: part 1-1: general rules and rules for buildings. BSI, London, UK.

691

692

BSI (2013) BSI 206:2013: Concrete - specification, performance, production and conformity. BSI, London, UK.

694

Clarke JL, O'Regan DP and Thirugnanenedran C (1996) Eurocrete Project, Modification of

Design Rules to Incorporate Non-Ferrous Reinforcement. Sir William Halcrow \& Partners, London, UK.

698

Clarke J, O'Regan D and Dill M (1998) Site testing and monitoring of fidgett footbridge. In Structural Assessment - The Role of Large and Full-Scale Testing (Virdi KS, Garas FK, Clarke JL and Armer GST (eds)). E \& FN Spon, London, UK, pp. 29-35.

702

CNR (Italian National Research Council) (2006) CNR-DT 206/2006: Guide for the Design and Construction of Concrete Structures Reinforced with Fiber-Reinforced Polymer Bars. CNR, Rome, Italy.

706

707 Cosenza E, Greco C, Manfredi G and Pecce M (1997) Flexural behaviour of concrete 708 beams reinforced with fibre reinforced plastic (FRP) bars. Proceedings of the 3rd 709 International Symposium on Non-Metallic (FRP) Reinforcement for Concrete Structures 710 (FRPRCS-3), Sapporo, Japan, vol. 2, pp. 463-470.

CSA (Canadian Standards Association) (1996) Canadian Highway Bridge Design Code, Section 16, Fiber Reinforced Structures. CSA, Mississauga, ON, Canada.

CSA (2002) CSA S806-02: Design and construction of building components with fiberreinforced polymers. CSA, Mississauga, ON, Canada.

718 CSA (2004) CSA A23.3-04: Design of concrete structures. CSA, Mississauga, ON, Canada. 
719 Cunningham L and Burgess A (2012) Design and construction of the tower headland 720 wave walls, Blackpool, UK. Proceedings of the Institution of Civil Engineers - Civil 721 Engineering 165(4): 171-178.

723 Cunningham L, Pomfret M and Robertshaw G (2012) Blackpool central area coast 724 protection scheme UK. Proceedings of the Institution of Civil Engineers - Maritime 725 Engineering 165(1): 21-29.

726

727 Daud R, Cunningham L and Wang Y (2017) New model for post-fatigue behaviour of 728 CFRP to concrete bond interface in single shear. Composite Structures 163: 63-76.

729

730 fib (Fédération Internationale du Béton) (2007) fib - TG 9.3: Technical Report: FRP 731 Reinforcement in RC Structures. fib, Lausanne, Switzerland.

732

733 Genikomsou AS and Polak MA (2015) Finite element analysis of punching shear of 734 concrete slabs using damaged plasticity model in ABAQUS. Engineering Structures 98: $73538-48$.

736

737 Gouverneur D, Caspeele R and Taerwe L (2013) Effect of reinforcement curtailment on 738 deflections, strain and crack development in

739 RC slabs under catenary action. Magazine of Concrete Research 65(22): 1336-1347.

740

741 Gremel D (2012) Ensuring electrical isolation in elevated rail. Concrete International $742 \quad 34(2): 22-25$.

743

744 Hollaway L (2010) A review of the present and future utilisation of FRP composites in the 745 civil infrastructure with reference to their important in-service properties. Construction 746 and Building Materials 24(12): 2419-2445.

747 
748 ISIS Canada (Intelligent Sensing for Innovative Structures) (2007) Design Manual No. 3 -

749 Reinforcing Concrete Structures with Fibre-Reinforced Polymers. ISIS Canada, MB, 750 Canada.

751

752 IStructE (The Institution of Structural Engineers) (1999) Interim Guidance on the Design 753 of Reinforced Concrete Structures Using Fibre Composite Reinforcement. IStructE, 754 London, UK, Technical report.

Jendele $L$ and Cervenka $J(2006)$ Finite element modelling of reinforcement with bond.

Computers and Structures 84(28): 1780-1791.

758

759

Kmiecik P and Kaminski M (2011) Modelling of reinforced concrete structures and composite structures with concrete strength degradation taken into consideration. Archives of Civil and Mechanical Engineering XI(3): 623-636.

Lin $X$ and Zhang Y (2014) Evaluation of bond stress-slip models for FRP reinforcing bars in concrete. Composite Structures 107: 131-141.

765

Mertol HC, Rizkalla S, Scott P, Lees JM and El-Hachal R (2006) Durability of concrete 767 beams prestressed with CFRP.

In Special Session-Subcommittee 440I for FRP Prestressed Concrete in ACl Fall Convention Denver, CO, USA, pp. 1-12.

Micelli F and Nanni A (2004) Durability of FRP rods for concrete structures. Construction and Building Materials 18(7): 491-503.

773

Nanni A and Dolan CW (eds) (1993) Fiber-Reinforced-Plastic Reinforcement for Concrete

775 Structures, Proceedings of the International Symposium, Vancouver, Canada. American Concrete Institute, Farmington Hills, MI, USA, ACI-SP138. 
778 Pilakoutas K, Neocleous K and Guadagnini M (2002) Design philosophy issues of FRP

779 RC structures. ASCE Journal of Composites for Construction 3(6): 154-161.

780

781 Pilakoutas K, Guadagnini M, Neocleous K and Matthys S (2011) Design guidelines for 782 FRP reinforced concrete structures. Proceedings of the Institution of Civil Engineers 783 Structures and Buildings 164(4): 255-263, http://dx.doi.org/10.1680/stbu.2011.164.4.255.

784

Rafi M, Nadjai A and Ali F (2007) Analytical modelling of concrete beams reinforced with 787

Railway Technology (2007) Miami-Dade Metrorail Transit. Railway Technology, Miami, FL, USA. See http://railway-technology.com (accessed 01/07/2014).

790

Shapira A and Bank LC (1997) Constructability and economics of FRP reinforcement cages for concrete beams. Journal of Composites for Construction 1(3): 82-89.

793

Shave $\mathrm{J}$ (2014) The time has come for high strength, low maintenance fibre reinforced 795 plastics. New Civil Engineer, 6 February: p. 11.

796

797 Simulia (2012) Abaqus 6.12 Documentation. Dassault Systèmes Simulia Corp, 798 Providence, RI, USA.

799

800 Stuart V (2014) Design of Concrete Elements Reinforced with Embedded Fibre 801 Reinforced Polymer (FRP) Rebar. Master's thesis, The University of Manchester, 802 Manchester, UK.

803

804 Wang T and Hsu T (2001) Nonlinear finite element analysis of concrete structures using 805 new constitutive models. Computers and Structures 79(32): 2781-2791.

806 Weaver A (1995) Bridge tests durability of rebar. Reinforced Plastics 39(7-8): 20-22. 